\title{
Prognostic models for breast cancer: a systematic review
}

\author{
Minh Tung Phung ${ }^{*}$ (D), Sandar Tin Tin and J. Mark Elwood
}

\begin{abstract}
Background: Breast cancer is the most common cancer in women worldwide, with a great diversity in outcomes among individual patients. The ability to accurately predict a breast cancer outcome is important to patients, physicians, researchers, and policy makers. Many models have been developed and tested in different settings. We systematically reviewed the prognostic models developed and/or validated for patients with breast cancer.
\end{abstract}

Methods: We conducted a systematic search in four electronic databases and some oncology websites, and a manual search in the bibliographies of the included studies. We identified original studies that were published prior to 1st January 2017, and presented the development and/or validation of models based mainly on clinico-pathological factors to predict mortality and/or recurrence in female breast cancer patients.

Results: From the 96 articles selected from 4095 citations found, we identified 58 models, which predicted mortality $(n=28)$, recurrence $(n=23)$, or both $(n=7)$. The most frequently used predictors were nodal status $(n=49)$, tumour size $(n=42)$, tumour grade $(n=29)$, age at diagnosis $(n=24)$, and oestrogen receptor status $(n=21)$. Models were developed in Europe $(n=25)$, Asia $(n=13)$, North America $(n=12)$, and Australia $(n=1)$ between 1982 and 2016. Models were validated in the development cohorts $(n=43)$ and/or independent populations $(n=17)$, by comparing the predicted outcomes with the observed outcomes $(n=55)$ and/or with the outcomes estimated by other models ( $n=32)$, or the outcomes estimated by individual prognostic factors $(n=8)$. The most commonly used methods were: Cox proportional hazards regression for model development $(n=32)$; the absolute differences between the predicted and observed outcomes $(n=30)$ for calibration; and C-index/AUC $(n=44)$ for discrimination. Overall, the models performed well in the development cohorts but less accurately in some independent populations, particularly in patients with high risk and young and elderly patients. An exception is the Nottingham Prognostic Index, which retains its predicting ability in most independent populations.

Conclusions: Many prognostic models have been developed for breast cancer, but only a few have been validated widely in different settings. Importantly, their performance was suboptimal in independent populations, particularly in patients with high risk and in young and elderly patients.

Keywords: Breast cancer, Prognostic model, Predictive model, Mortality, Survival, Recurrence, Prognosis, Nottingham prognostic index, Adjuvant!Online, PREDICT

\section{Background}

Breast cancer is the most common cancer in women worldwide [1]. The disease is highly heterogeneous with wide variations in prognosis [2]. Prognosis means the probability or risk that an outcome (such as deaths, complications, quality of life, pain, or disease regression) develops over a specific time, based on both clinical and

\footnotetext{
* Correspondence: tphu014@aucklanduni.ac.nz

Epidemiology and Biostatistics, School of Population Health, The University

of Auckland, Private Bag 92019, Auckland 1142, New Zealand
}

non-clinical profiles [3]. In breast cancer patients, 5-year relapse-free survival (RFS) ranges from 65 to $80 \%$ [4], and 10-year overall survival (OS) ranges from 55 to $96 \%$ [5].

Prognosis for breast cancer is important in several ways. Firstly, it informs patients about the future course of their illness [3]. Two Australian surveys found that survival time information was desired by 87 and $85 \%$ of early and metastatic breast cancer patients, respectively [6, 7]. Secondly, prognosis is essential for breast cancer treatment: the more precise is the outcome predicted, the better a

(c) The Author(s). 2019 Open Access This article is distributed under the terms of the Creative Commons Attribution 4.0 International License (http://creativecommons.org/licenses/by/4.0/), which permits unrestricted use, distribution, and 
patient is allocated the right treatment [3, 8-10]. For example, patients whose prognosis is very poor may be considered for aggressive treatments, while those with a good prognosis may be saved from overtreatment and its related side-effects and financial costs [11, 12]. Thirdly, prognosis can be used for the inclusion and stratification of patients in experimental studies [8,9]. Finally, prognosis helps policy makers compare mortality rates among hospitals and institutions $[3,13]$.

Many models have been developed to predict breast cancer prognosis. The number of models has increased rapidly, accompanying with the great variance in terms of patients included, methods of development, predictors, outcomes, presentations, and performance in different settings [11, 14]. Nevertheless, to our knowledge, only two reviews of prognostic models for breast cancer have been conducted, but with limitations. An earlier review reported 54 models that were developed between 1982 and 2001, with a focus on model development methods rather than model performance in different populations [11]. A more recent review included only 26 models published up to July 2012 [14]. This systematic review was undertaken to identify all prognostic models that have been published up to 2017, and to assess how the models performed in different settings.

\section{Methods}

\section{Study search}

A systematic search was conducted in EMBASE, PUBMED, Web of Science, COCHRANE, and in specific breast cancer and oncology websites, including: American Society of Clinical Oncology (ASCO) https://www. asco.org/, Journal of the National Comprehensive Cancer Network (JNCCN) http://www.jnccn.org/, Memorial Sloan Kettering Cancer Centre (MSKCC) https://www. mskcc.org/, MD Anderson Cancer Centre https://www. mdanderson.org/, Mayo Clinic http://www.mayoclinic. org/, and European Society for Medical Oncology (ESMO) http://www.esmo.org/. A manual search in the bibliographies of selected articles was also conducted. The search terms used were "prognostic model", "breast cancer", and their synonyms (see details in Additional file 1).

\section{Eligibility criteria}

This review included all research articles that presented the development and/or validation of prognostic models for female breast cancer, were published in English prior to 1st January 2017 and were available in full text. The review was restricted to the models that were developed based on at least two different clinico-pathological factors and/or commonly used biomolecular factors, such as hormonal receptor status or human epidermal growth factor receptor 2 (HER2) status, and predicted mortality and/or recurrence of women who were diagnosed with primary breast cancer. Articles that reported the development of a model for specific patient groups (those with invasive ductal carcinoma or invasive lobular carcinoma, those who have undergone surgery) were included. Articles that presented the development of a model for rare histological subtypes of breast cancer or special types of patients (such as those with metastases, those with hormonal receptor negative or positive, those with node negative or positive, those with neoadjuvant or adjuvant therapy) were excluded due to their limited generalisability.

\section{Study selection and data extraction}

Publications were screened in three levels - titles, abstracts, and full texts. From each selected article, relevant information was extracted into a data extraction sheet using the TRIPOD [15] and CHAMRS checklist [16], and included: authors, year of publication, objectives, name of models, study design, source of data, targeted populations, methods of development and/or validation, risk groups, outcomes, predictors, results of the development and/or validation, limitations and strengths.

The selected articles were categorised into three groups: those that presented model development, those that presented internal validation, and those that presented external validation. For the articles that presented the development of more than one model, we reviewed the best model only if the study indicated the best model, or we reviewed all the models presented if the study did not select the best model. Internal validation is defined here as the validation of a model in participants selected from the model development cohorts, or in patients recruited from the same source as in the development cohorts but at different times. External validation is defined as the validation of a model in patients from sources independent from the development cohorts [8].

\section{Assessment of risk of bias in individual studies}

The risk of bias within individual studies was assessed by using a modified version of the QUIPS (QUality In Prognosis Studies) tool, which was originally designed to assess bias in studies of prognostic factors $[17,18]$. The tool originally comprises six domains - Study Participation, Prognostic Factor Measurement, Outcome Measurement, Statistical Analysis and Reporting, Study Confounding, and Study Attrition, each of which is guided by three to seven prompting items. The last two domains were omitted as these are not relevant to the studies included in this review. The overall rating for each of the remaining four domains was assigned as low, moderate, or high risk of bias [17].

The risk of bias was assessed separately for development (and internal validation) studies and external validation 
studies. For articles that presented both model development and external validation, the risk of bias was assessed separately for each part. For articles that presented internal validation without model development, the risk of bias was assessed similarly to the external validation studies.

\section{Results}

The systematic search in the four databases generated 4084 records, supplemented by 11 publications found in other sources (Fig. 1). We excluded 2466 duplicates. We screened the titles and then the abstracts of the remaining records and excluded 1355 records. We reviewed the full text of the remaining 274 articles and identified 96 eligible articles, of which 54 presented model development, 42 presented internal validation and 49 presented external validation. Twenty four studies that met the eligibility criteria but were not available in full text are presented in Additional file 2 (model development) and Additional file 3 (model validation).

\section{Study characteristics}

The studies were published between 1982 and 2016, mostly retrospective and hospital-based. Participants were mostly from Europe, Asia, and North America (Table 1).

Of the 54 model development studies identified, 42 developed only one model, nine developed more than one model and selected the best performing model(s) [19-27], whereas three studies developed more than one model but did not select the best model(s) [28-30]. In total, we reviewed 58 models. More detailed information about each development study is presented in Additional file 4.

Among the 42 internal validation studies, 38 developed models and validated them, while four only validated the existing models: three studies validated the Nottingham Prognostic Index (NPI) [31-33], and one validated the Morphometric Prognostic Index (MPI) [34] (see details in Additional file 5).

Of the 49 external validation studies, 38 validated the existing models only, 10 developed new models and then validated them [19, 35-43], and one externally validated an existing model (Adjuvant!) and then developed a new model [44]. More detailed information about the external validation studies is presented in Additional file 6.

\section{Risk of bias in individual studies}

The risk of bias was assessed for 54 studies in the development part (Table 2), and 53 studies in the validation part (Table 3). In all the four domains of the QUIPS tool, most studies had low or moderate risk of bias while only a small number were at high risk of bias.

\section{Model development}

Of the 58 models identified, 49 were developed independently, while nine were derived from the existing models, of which five were derived from the NPI, one from Adjuvant!, one from IBTR! (the model predicts the risk of ipsilateral breast tumour recurrence), and two from PREDICT v1.1. The version PREDICT v1.2, also called PREDICT+, added HER2 status as a predictor into the first version PREDICT v1.1 [35]. The version PREDICT v1.3 added Ki67, a nuclear protein used as a marker of cell proliferation, into PREDICT v1.2 [36].

The models predicted mortality $(n=28)$, recurrence $(n=$ $23)$, or both $(n=7)$, mostly based on participants in Europe $(n=25)$, followed by Asia $(n=13)$, North America $(n=12)$, and Australia $(n=1)$. Cox proportional hazards $(\mathrm{PH})$ regression $(n=32)$ was the most commonly used method for model development, followed by artificial neural networks $(n=6)$, decision trees $(n=4)$, logistic regression $(n=3)$, and Bayesian methods $(n=3)$. The most commonly used predictors include nodal status $(n=49)$, tumour size $(n=$ $42)$, tumour grade $(n=29)$, age at diagnosis $(n=24)$, and oestrogen receptor (ER) status $(n=21)$. The models were presented as regression formula $(n=13)$, followed by online tools $(n=8)$, decision trees $(n=5)$, nomograms $(n=4)$ and score chart $(n=1)$ (Table 4).

Seventeen models have been externally validated by independent researchers $(n=8)$ or by the model developers $(n=15)$. These models were developed to support clinical decision making $(n=14)$ or evaluating the prognostic value of specified clinical factors $(n=3)$ (Additional file 7 ). Additional file 8 presents the characteristics of these models.

The models that were most frequently validated include Adjuvant! $(n=17)$, the NPI $(n=15)$, and PREDICT v1.3 $(n=5)$. Among the 17 studies that externally validated Adjuvant!, three had high risk of bias in Prognostic Factor Measurements [35, 45, 46], one was at low risk of bias across the QUIPS domains [47], while the remaining studies had low or moderate risk of bias. Among the 15 studies that externally validated the NPI, three were at high risk of bias in Prognostic Factor Measurement [37, 48, 49], one was at high risk of bias in Statistical Analysis and Presentation [50], three were at low risk across the domains $[47,51,52]$, and the rest had low or moderate risk of bias. All the five studies that externally validated PREDICT v1.3 had low or moderate risk of bias (Table 5).

While the web-based programmes Adjuvant! and PREDICT v1.3 estimate the possible survival time for breast cancer patients, the NPI assigns a prognostic index (PI) score to each individual patient based on the calculation (0.2x tumour size in $\mathrm{cm})+$ lymph node stage + tumour grade. Originally, the NPI was developed based on the lymph node stage, but later the authors suggested that the number of involved nodes can replace the lymph node 


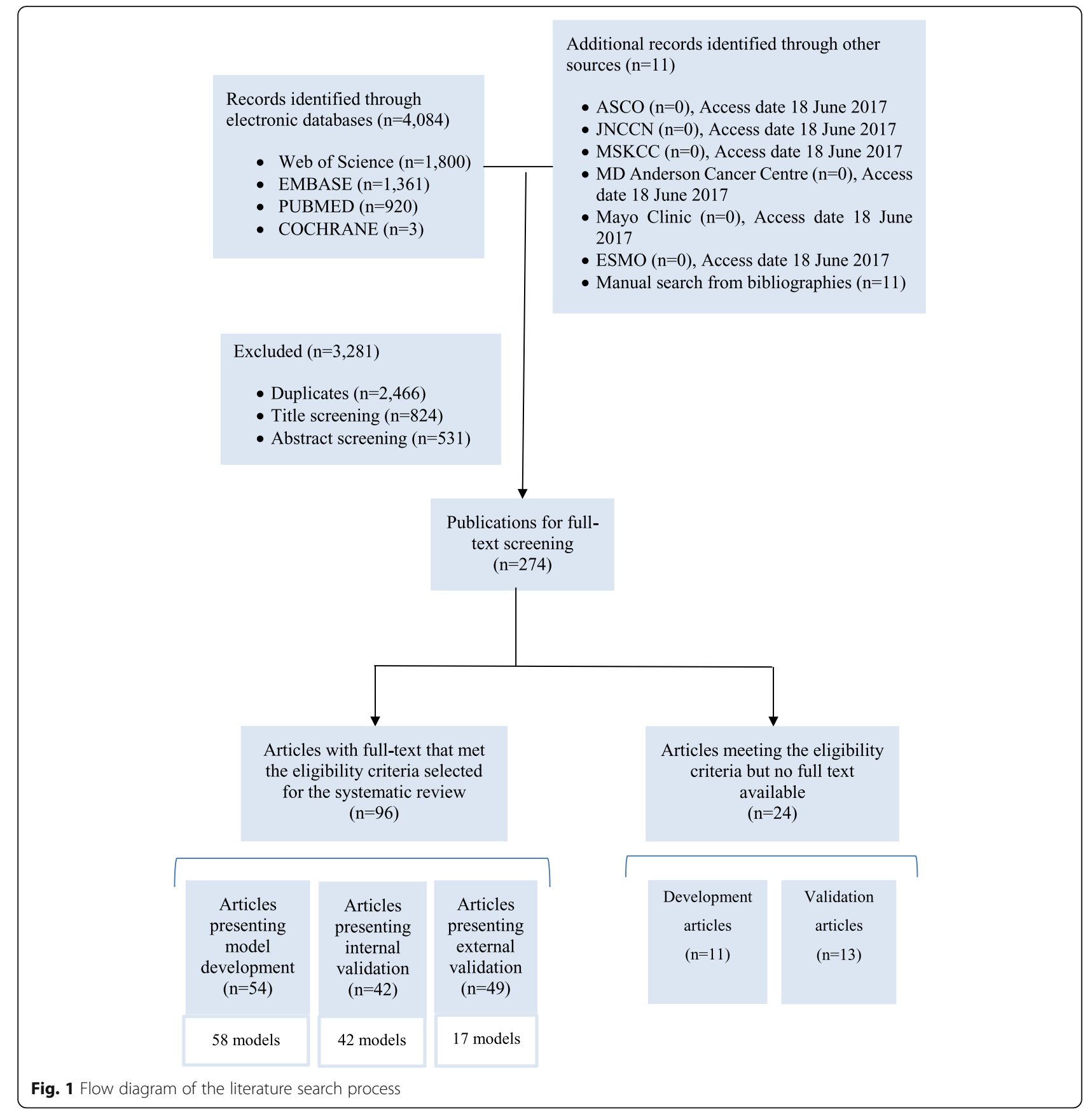

stage [32]. At the outset, a patient will be classified into one of three prognostic groups based on their NPI score: good prognostic group $(\mathrm{PI}<3.4)$, moderate prognostic group $(3.4 \leq \mathrm{PI} \leq 5.4)$, and poor prognostic group (PI>5.4) [53]. Some validation studies of the NPI further divided the samples into six smaller prognostic groups $[47,54]$.

\section{Model validation}

\section{Internal validation}

Forty two models were internally validated by comparing the predicted outcomes to (a) the observed outcomes $(n=$
20); (b) the outcomes predicted by the NPI or Adjuvant! ( $n$ $=7$ ); (c) the outcomes predicted by prognostic factors $(n=$ 4); or (d) the outcomes predicted by other newly developed models $(n=15)$. The sampling methods for internal validation were cross-validation $(n=13)$, random-splitting $(n=$ $11)$, or bootstrap $(n=5)$; some internal validation cohorts were exactly the same to the development cohorts $(n=13)$, or they were the development cohorts with longer follow-up $(n=1)$, or they were specific subgroups of the development cohorts $(n=1)$, or they were the combination of the development cohorts and the newly recruited patients 
Table 1 Characteristics of the studies selected for the systematic review

\begin{tabular}{|c|c|c|c|}
\hline Characteristics & Model development studies & Internal validation studies & External validation studies \\
\hline Number of studies & 54 studies & 42 studies & 49 studies \\
\hline Number of models & 58 models & 42 models & 17 models \\
\hline Year of publication & 1982-2016 & 1982-2016 & 1987-2016 \\
\hline \multicolumn{4}{|l|}{ Study design } \\
\hline Prospective & 2 studies & 2 studies & 0 study \\
\hline Retrospective & 32 studies & 23 studies & 30 studies \\
\hline Unknown & 20 studies & 18 studies & 19 studies \\
\hline \multicolumn{4}{|l|}{ Source of data } \\
\hline Population-based & 14 studies & 11 studies & 12 studies \\
\hline Hospital-based & 31 studies & 29 studies & 33 studies \\
\hline RCT-based & 6 studies & 1 study & 4 studies \\
\hline Unknown & 3 studies & 2 studies & 0 study \\
\hline Sample size & $75-433,272$ & $30-433,272$ & $48-387,262$ \\
\hline \multicolumn{4}{|l|}{ Number of events } \\
\hline Deaths & $27-24,610$ & $27-24,610$ & $11-3902$ \\
\hline Recurrences & $5-1030$ & $5-950$ & $9-1188$ \\
\hline \multicolumn{4}{|l|}{ Country of participants } \\
\hline Europe & 24 studies & 22 studies & 29 studies \\
\hline North America & 13 studies & 8 studies & 7 studies \\
\hline Asia & 11 studies & 10 studies & 11 studies \\
\hline Others & 2 studies (Australia) & 0 study & $\begin{array}{l}3 \text { studies (1 Australia. } 1 \\
\text { New Zealand, } 1 \text { Brazil) }\end{array}$ \\
\hline \multicolumn{4}{|c|}{ Strengths concluded by the authors of the selected studies } \\
\hline Adhere to good practice & 1 study & 1 study & 0 study \\
\hline Large sample size & 2 studies & 2 studies & 4 studies \\
\hline Patients diagnosed recently & 1 study & 1 study & 0 study \\
\hline Homogeneous source of data & 2 studies & 2 studies & 1 study \\
\hline Low proportion of missing data & 0 study & 0 study & 1 study \\
\hline \multicolumn{4}{|c|}{ Weaknesses concluded by the authors of the selected studies } \\
\hline Missing data & 11 studies & 11 studies & 8 studies \\
\hline Small sample size & 3 studies & 3 studies & 9 studies \\
\hline Patients treated with obsolete methods & 4 studies & 4 studies & 3 studies \\
\hline Heterogeneous source of data & 3 studies & 3 studies & 0 study \\
\hline Selection bias & 2 studies & 2 studies & 0 study \\
\hline Short-time follow-up & 1 study & 1 study & 0 study \\
\hline
\end{tabular}

in the same centres $(n=1)$, or they were different patients from the development cohorts but in the same hospitals $(n=1)$. The models were assessed for overall performance $(n=3)$, calibration (the level of agreement between the predicted and observed outcomes) $(n=12)$, discrimination (the extent to which a model can discriminate patients with the outcomes and those without the outcomes) $(n=28)$, and clinical usefulness $(n=13)$. Brier scores $(n=2)$, calibration plots $(n=7)$, Kaplan-Meier curves $(n=23)$, and accuracy rates $(n=11)$ were most commonly used to assess the models' overall performance, calibration, discrimination, and clinical usefulness, respectively (Table 6).

Overall, most models performed well in the internal validation cohorts, some even showed better performance than the existing models $[19,22,37,44,55,56]$ or prognostic factors $[43,53,57]$.

\section{External validation}

Only 17 models have been externally validated by comparing the predicted outcomes with the observed outcomes 
Table 2 Risk of bias within model development studies

\begin{tabular}{|c|c|c|c|c|c|}
\hline No & Citation & $\begin{array}{l}\text { Study } \\
\text { Participation }\end{array}$ & $\begin{array}{l}\text { Prognostic Factor } \\
\text { Measurement }\end{array}$ & $\begin{array}{l}\text { Outcome } \\
\text { Measurement }\end{array}$ & $\begin{array}{l}\text { Statistical Analysis and } \\
\text { Presentation }\end{array}$ \\
\hline 1 & Asare et al. (2016) [107] & Low & Moderate & Moderate & Moderate \\
\hline 2 & Baak et al. (1985) [108] & Low & Moderate & Low & Moderate \\
\hline 3 & Broet et al. (1999) [109] & Low & Moderate & Moderate & Low \\
\hline 4 & Brown et al. (1993) [110] & Moderate & Moderate & Low & Moderate \\
\hline 5 & Bryan et al. (1986) [111] & Moderate & Low & Low & Low \\
\hline 6 & Bucinski et al. (2005) [112] & High & Moderate & High & Moderate \\
\hline 7 & Campbell et al. (2010) [19] & Low & Low & Moderate & Low \\
\hline 8 & Chao et al. (2014) [20] & Moderate & High & Low & Moderate \\
\hline 9 & Chen et al. (2016) [41] & Moderate & High & Low & Low \\
\hline 10 & Cheng et al. (2006) [30] & Low & Moderate & High & Low \\
\hline 11 & Choi et al. (2009) [25] & Low & High & Low & Moderate \\
\hline 12 & Collan et al. (1994) [113] & Moderate & Low & Low & Moderate \\
\hline 13 & de Laurentiis et al. (1999) [43] & Low & Moderate & Moderate & Moderate \\
\hline 14 & Delen et al. (2005) [27] & Moderate & Moderate & Low & Moderate \\
\hline 15 & Eskelinen et al. (1992) [10] & Moderate & Low & Moderate & Low \\
\hline 16 & Fan et al. (2011) [56] & Low & Moderate & Low & Low \\
\hline 17 & Fleming et al. (1999) [21] & Low & Moderate & Low & Moderate \\
\hline 18 & Fuster et al. (1983) [114] & High & High & Low & Moderate \\
\hline 19 & Gomez-Ruiz et al. (2004) [97] & Moderate & High & High & Moderate \\
\hline 20 & Hawkins et al. (2002) [89] & Moderate & Low & Moderate & Moderate \\
\hline 21 & Haybittle et al. (1982) [53] & Moderate & Low & Low & Moderate \\
\hline 22 & Jerez Aragones et al. (2004) [115] & Moderate & High & Low & Moderate \\
\hline 23 & Jerez et al. (2005) [26] & Low & Moderate & High & Low \\
\hline 24 & Jhajharia et al. (2016) [116] & Moderate & High & Low & Moderate \\
\hline 25 & M. Jung et al. (2013) [44] & Low & Moderate & Low & Moderate \\
\hline 26 & Kim et al. (2012) [22] & Low & High & High & Low \\
\hline 27 & Kim et al. (2016) [117] & Moderate & High & High & Low \\
\hline 28 & Lisboa et al. (2003) [23] & Moderate & High & Low & High \\
\hline 29 & Y.Q. Liu et al. (2009) [118] & Moderate & Moderate & Low & Moderate \\
\hline 30 & Lovekin et al. (1991) [119] & High & Moderate & Low & Moderate \\
\hline 31 & Masarwah et al. (2016) [55] & Moderate & Low & High & Low \\
\hline 32 & Mazouni et al. (2011) [120] & Moderate & Moderate & Low & Low \\
\hline 33 & Michaelson et al. (2011) [42] & Moderate & High & Low & Moderate \\
\hline 34 & Musial et al. (2005) [121] & Moderate & Moderate & Low & Low \\
\hline 35 & Ni et al. (2014) [122] & Moderate & Moderate & High & Low \\
\hline 36 & Paik et al. (1990) [123] & Moderate & Low & Low & Moderate \\
\hline 37 & Putter et al. (2006) [124] & Moderate & Moderate & Moderate & Moderate \\
\hline 38 & Rakha et al. (2014) [90] & Moderate & Moderate & Low & Moderate \\
\hline 39 & Ravdin et al. (2001) [125] & Low & High & Moderate & Moderate \\
\hline 40 & Ripley et al. (1998) [29] & Moderate & High & High & Moderate \\
\hline 41 & Sanghani et al. (2007) [126] & High & High & High & Moderate \\
\hline 42 & Sanghani et al. (2010) [38] & Low & High & Moderate & Moderate \\
\hline 43 & Shek \& Godolphin (1988) [127] & Low & Moderate & Low & Moderate \\
\hline
\end{tabular}


Table 2 Risk of bias within model development studies (Continued)

\begin{tabular}{|c|c|c|c|c|c|}
\hline No & Citation & $\begin{array}{l}\text { Study } \\
\text { Participation }\end{array}$ & $\begin{array}{l}\text { Prognostic Factor } \\
\text { Measurement }\end{array}$ & $\begin{array}{l}\text { Outcome } \\
\text { Measurement }\end{array}$ & $\begin{array}{l}\text { Statistical Analysis and } \\
\text { Presentation }\end{array}$ \\
\hline 44 & Suen \& Chow (2006) [91] & Low & Low & Moderate & Low \\
\hline 45 & Tokatli et al. (2011) [28] & Moderate & Moderate & High & Low \\
\hline 46 & Ture et al. (2009) [24] & Moderate & High & High & Low \\
\hline 47 & van Belle et al. (2010b) [37] & Low & Low & High & Low \\
\hline 48 & van Nes et al. (2010) [128] & Moderate & High & Moderate & Moderate \\
\hline 49 & Wen et al. (2015) [129] & Low & Moderate & Low & Low \\
\hline 50 & Wen et al. (2016) [57] & Low & Moderate & Low & Low \\
\hline 51 & Wishart et al. (2010b) [40] & Low & High & Low & Low \\
\hline 52 & Wishart et al. (2012) [35] & Moderate & Moderate & Low & Low \\
\hline 53 & Wishart et al. (2014) [36] & Moderate & Low & Low & Low \\
\hline 54 & Witteveen et al. (2015) [39] & Low & Moderate & High & Low \\
\hline
\end{tabular}

$(n=35)$, with the outcomes predicted by other models ( $n$ $=10$ ), or with the outcomes predicted by single prognostic factors $(n=4)$. Participants were recruited in countries different from the development cohorts $(n=39)$ or in the same countries but different centres/sources $(n=9)$. The models were assessed for overall performance $(n=2)$ (using explained variation $\mathrm{R}^{2}(n=1)$ and Brier score $(n=1))$; calibration $(n=32)$ (mainly using calibration plots $(n=20)$ and/or the comparison of the predicted (E) to the observed outcomes $(\mathrm{O})(n=30))$; discrimination $(n=37)$ (mainly using Harrell's C-index/AUC (Area under the Receiver operating characteristic (ROC) curve) $(n=22)$, Kaplan-Meier curve $(n=20)$, and/or log-rank test $(n=18))$; and clinical usefulness $(n=2)$ (using accuracy rate $(n=2)$ and sensitivity/specificity $(n=1))$. Some studies that compared two or more models tested the agreement between the models $(n=4)$, using Kappa coefficient $(\kappa)(n=1)$ and correlation coefficients (Pearson or Spearman) $(n=3)$. Univariate $(n=10)$ and multivariate analysis $(n=6)$ were used to test if prognostic factors and prognostic scores were significant to outcomes (Table 6). A summary of the external validation studies is presented in Additional file 9.

In general, the models performed less accurately in some independent populations, particularly in patients with high risk, in young and elderly patients. For example, Adjuvant! predicted prognosis accurately in patients from France [58], Canada [45, 46], and those with low grade tumours, but less accurate in patients from UK [59], Ireland [60], Malaysia [61], South Korea [44], Taiwan [62], those with lympho-vascular invasion [45, 61], BRCA1-mutation carriers [63], and those with high grade tumours $[44,58,59,61,62]$. Studies showed inconsistent results of Adjuvant! in patients aged 40 years or less $[35,44-47,54,58,59,61,62,64]$ and elderly patients [45, 46, 54, 59, 61, 65, 66]. Similarly, PREDICT v1.3 performed well in Malaysian patients [67], but less accurately in patients with BRCA1 mutations [63], patients aged 40 years or less [67], and those with ER positive and HER2 negative tumours [68], and inconsistently in elderly patients $[67,69]$. An exception is the NPI, which performed well in most populations, including patients from Italy [51, 70, 71], Sweden [72], Denmark [48], Belgium [73], Norway [37], Japan [52], India [50], New Zealand [37], patients aged 40 years or less [47], metastatic patients [74], those with triple negative breast cancer [75], and those treated with neoadjuvant chemotherapy [49].

\section{Studies that compared different models in independent datasets}

In the three studies that compared the NPI and Adjuvant! conducted by independent researchers, no model was shown to be better than the other. One study showed that both models performed accurately in the overall cohort of Iranian patients, but less accurately in some subgroups [54]. Another study found that Adjuvant! showed better discrimination ability than the NPI in Irish breast cancer patients, although Adjuvant! underestimated the 10-year OS [60]. However, the third study showed that, in British breast cancer patients aged 40 years or less, the NPI's prediction was nearly similar to the observed outcomes, while Adjuvant! seemed to overestimate the 10-year OS, although the study power was not sufficient to generate a statistically significant difference [47] (see details in Additional file 10).

None of the three models compared by independent researchers- PREDICT v1.3, Adjuvant!, and CancerMath- was found to be superior. In the studies that compared PREDICT v1.3 and Adjuvant!, both did not predict the 10-year OS well in BRCA1-mutation carriers [63] and in patients aged 65 years or more $[66,69]$, with statistically significant differences between the predicted 
Table 3 Risk of bias within model validation studies

\begin{tabular}{|c|c|c|c|c|c|}
\hline No & Citation & $\begin{array}{l}\text { Study } \\
\text { Participation }\end{array}$ & $\begin{array}{l}\text { Prognostic Factor } \\
\text { Measurement }\end{array}$ & $\begin{array}{l}\text { Outcome } \\
\text { Measurement }\end{array}$ & $\begin{array}{l}\text { Statistical Analysis and } \\
\text { Presentation }\end{array}$ \\
\hline 1 & Aaltomaa et al. (1983) [130] & Low & Low & Low & Low \\
\hline 2 & Albergaria et al. (2011) [75] & Moderate & Moderate & Low & Low \\
\hline 3 & Alexander et al. (1987) [131] & Low & Low & Low & Low \\
\hline 4 & Balslev et al. (1994) [48] & Low & High & Low & Low \\
\hline 5 & Bhoo-Pathy et al. (2012) [61] & Low & Moderate & Moderate & Low \\
\hline 6 & Campbell et al. (2009) [59] & Low & Moderate & Low & Low \\
\hline 7 & Campbell et al. (2010) [19] & Moderate & Low & Moderate & Moderate \\
\hline 8 & Carbone et al. (1999) [132] & Moderate & Low & Low & Low \\
\hline 9 & Chen et al. (2016) [41] & Low & High & Low & Low \\
\hline 10 & Chollet et al. (2003) [49] & Moderate & High & Low & Low \\
\hline 11 & Collan et al. (1998) [98] & Moderate & Low & Low & Low \\
\hline 12 & de Glas et al. (2014) [66] & Low & Moderate & Low & Low \\
\hline 13 & de Glas et al. (2016) [69] & Low & Moderate & Low & Low \\
\hline 14 & de Laurentiis et al. (1999) [43] & Moderate & Low & Moderate & Moderate \\
\hline 15 & D'Eredita et al. (2001) [51] & Low & Low & Low & Low \\
\hline 16 & Galea et al. (1992) [32] & Moderate & Moderate & Low & Moderate \\
\hline 17 & Green et al. (2016) [133] & Low & Moderate & Low & Low \\
\hline 18 & Hajage et al. (2011) [58] & Moderate & Low & Moderate & Low \\
\hline 19 & Hearne et al. (2015) [47] & Low & Low & Low & Low \\
\hline 20 & S.P. Jung et al. (2013) [134] & Low & Moderate & Low & Low \\
\hline 21 & M. Jung et al. (2013) [44] & Low & Moderate & Moderate & Low \\
\hline 22 & Kindts et al. (2016) [135] & Moderate & Moderate & Moderate & Low \\
\hline 23 & Kollias et al. (1999) [31] & Moderate & Moderate & Low & Moderate \\
\hline 24 & Kuo et al. (2012) [62] & Low & Low & Moderate & Low \\
\hline 25 & Laas et al. (2015) [68] & Moderate & Moderate & Moderate & Low \\
\hline 26 & Lende et al. (2010) [136] & Low & Moderate & Low & Low \\
\hline 27 & M. Liu et al. (2010) [74] & Low & Moderate & Low & Low \\
\hline 28 & Maishman et al. (2015) [137] & Moderate & Moderate & Low & Low \\
\hline 29 & Megha et al. (2010) [70] & Moderate & Moderate & Low & Low \\
\hline 30 & Miao et al. (2016) [138] & Moderate & High & Low & Low \\
\hline 31 & Michaelson et al. (2011) [42] & Low & High & Low & Moderate \\
\hline 32 & Mojir Sheibani et al. (2013) [65] & Low & Low & Moderate & Low \\
\hline 33 & Mook et al. (2009) [64] & Low & Moderate & Moderate & Low \\
\hline 34 & Okugawa et al. (2009) [52] & Low & Low & Low & Low \\
\hline 35 & Olivotto et al. (2005) [45] & Low & High & Low & Low \\
\hline 36 & Plakhins et al. (2013) [63] & Moderate & Moderate & Low & Low \\
\hline 37 & Quintyne et al. (2013) [60] & Low & Moderate & Moderate & Low \\
\hline 38 & Rejali et al. (2015) [54] & Moderate & Moderate & Moderate & Low \\
\hline 39 & Ribelles et al. (1997) [139] & Moderate & Low & Low & Low \\
\hline 40 & Sanghani et al. (2010) [38] & Moderate & Moderate & Moderate & Low \\
\hline 41 & Sidoni et al. (2004) [71] & Moderate & Low & Low & Low \\
\hline 42 & Sundquist et al. (1999) [72] & Low & Moderate & Low & Low \\
\hline 43 & Todd et al. (1987) [33] & High & Low & Low & Moderate \\
\hline
\end{tabular}


Table 3 Risk of bias within model validation studies (Continued)

\begin{tabular}{|c|c|c|c|c|c|}
\hline No & Citation & $\begin{array}{l}\text { Study } \\
\text { Participation }\end{array}$ & $\begin{array}{l}\text { Prognostic Factor } \\
\text { Measurement }\end{array}$ & $\begin{array}{l}\text { Outcome } \\
\text { Measurement }\end{array}$ & $\begin{array}{l}\text { Statistical Analysis ano } \\
\text { Presentation }\end{array}$ \\
\hline 44 & van Belle et al. (2010a) [73] & Low & Moderate & Low & Low \\
\hline 45 & van Belle et al. (2010b) [37] & Low & High & Low & Low \\
\hline 46 & van Diest \& Baak (1991) [34] & Low & Moderate & Low & Low \\
\hline 47 & Wishart et al. (2010b) [40] & Low & High & Low & Low \\
\hline 48 & Wishart et al. (2011) [46] & Low & High & Low & Low \\
\hline 49 & Wishart et al. (2012) [35] & Low & High & Low & Low \\
\hline 50 & Wishart et al. (2014) [36] & Low & Moderate & Low & Low \\
\hline 51 & Witteveen et al. (2015) [39] & Low & Moderate & High & Low \\
\hline 52 & Wong et al. (2015) [67] & Low & Moderate & Low & Low \\
\hline 53 & Yadav et al. (2015) [50] & Moderate & Moderate & Low & High \\
\hline
\end{tabular}

and observed outcomes $(P<0.05)$. PREDICT v1.3 accurately predicted the 5 -year OS in elderly patients, though not in all subgroups, but the authors could not compare that model with Adjuvant! because the latter did not predict the 5-year OS [69]. When PREDICT v1.3, Adjuvant!, and CancerMath were compared in patients with ER positive and HER2 negative tumours, all the three models inaccurately predicted the 10-year OS, with statistically significant differences between the predicted and observed outcomes $(P<0.05)$ [68] (see details in Additional file 10).

There are four studies that developed new models, and then compared them to existing models in independent datasets (see details in Additional file 11). In its development study, PREDICT v1.1 showed better performance than Adjuvant! in predicting 10-year breast cancer specific survival (BCSS), but poorer performance in 10-year OS in the overall cohort [46]. PREDICT v1.1 was better in some sub-groups (10-year OS in patients with grade 3 tumours, lymphovascular positive tumours, and node negative tumours; 10-year BCSS in patients with node positive tumours, tumour size $>21 \mathrm{~mm}$, and ER positive tumours), whereas Adjuvant! was better in others (10-year OS in patients with tumour size $>21$ $\mathrm{mm}$, grade 2 tumours, and ER positive tumours; 10-year BCSS in patients with grade 3 tumours, ER negative tumours, and node negative tumours) [46]. In its development study, PREDICT v1.2 showed significantly better performance than PREDICT v1.1 and Adjuvant! in the HER2 positive subgroup, possibly because it was developed by adding HER2 status as a prognostic factor into PREDICT v1.1 [35]. However, in the overall cohort, Adjuvant! was better in predicting OS while both versions of PREDICT were better in predicting BCSS [35]. The development study of the iNPI showed that this version discriminated slightly better than the original version NPI, but the difference was not significant [37]. The development study of PREDICT v1.3 showed that this new version improved both calibration and discrimination compared to the previous version PREDICT v1.2 in patients with ER positive tumours [36].

\section{Discussion}

This study reviewed 96 articles that presented the development and/or validation of prognostic models for breast cancer. To our knowledge, this is the most comprehensive review of prognostic models for breast cancer. A previous review reported only six models based on clinico-pathological factors [14]. However, our findings may be affected by publication bias $[8,76]$ as well as the diversity of terms used in prognostic research $[14,77]$. The review may have missed some relevant studies that were published after December 2016, for example, PREDICT v2.0, which added age at diagnosis as a predictor into PREDICT v1.3 [78].

Due to the heterogeneity of study designs, inclusion criteria, measurement techniques, methods of analysis, and methods of handling of continuous variables, meta-analysis was not undertaken as recommended previously $[76,79]$. Instead, we assessed the risk of bias for each individual study using the modified QUIPS tool.

The original QUIPS tool was developed to assess bias in studies establishing the relationship between a prognostic factor and an outcome [17], in which confounders may play an important role. In contrast, we are interested in outcome prediction studies where causality and confounding are not a concern [9]. Therefore, we did not assess the confounding issue of the selected articles. We also omitted the domain of Study Attrition because, although most of the selected studies described attempts to track loss to follow-up to some extent, none of them reported specific information required by the QUIPS tool (including: the proportion of study sample dropping out of the study, attempts to collect their information, reasons for loss to follow-up, their key characteristics, and if these characteristics are different from those who completed the study [17]). 
Table 4 Characteristics of the models

\begin{tabular}{ll}
\hline & Number of models \\
\hline Total & 58 models \\
Types of models & \\
New models & 49 models \\
Modified models & 9 models \\
Year of development & $1982-2016$ \\
1982-1989 & 5 models \\
1990-1999 & 11 models \\
2000-2009 & 17 models \\
2010-2016 & 25 models \\
Country of participants for model development \\
Europe & 25 models \\
Asia & 13 models \\
North America & 12 models \\
Others & 1 model (Australia) \\
Unknown or from several trials & 7 models \\
Method of model development & \\
Cox PH regression & 32 models \\
Artificial neural networks & 6 models \\
Decision tree & 4 models \\
Logistic regression & 3 models \\
Bayesian method & 3 models \\
Multistate model & 2 models \\
Support vector machine & 2 models \\
Others & 6 models \\
\hline
\end{tabular}

Outcomes

$\begin{array}{ll}\text { Mortality } & 28 \text { models } \\ \text { Recurrence } & 23 \text { models } \\ \text { Both } & 7 \text { models }\end{array}$

Predictors

$\begin{array}{ll}\text { Age at diagnosis } & 24 \text { models } \\ \text { Nodal status } & 49 \text { models } \\ \text { Tumour size } & 42 \text { models } \\ \text { Tumour grade } & 29 \text { models } \\ \text { Lympho-vascular invasion (LVI) } & 8 \text { models } \\ \text { Stage } & 8 \text { models } \\ \text { ER status } & 21 \text { models } \\ \text { Progesterone receptor (PR) status } & 10 \text { models } \\ \text { HER2 status } & 13 \text { models } \\ \text { Treatment } & 17 \text { models } \\ \text { Others } & \text { Mitotic activity index (MAI), } \\ & \text { histological subtypes, comorbidity, } \\ & \text { menopausal status, etc. }\end{array}$

Presentation of model

Regression formula 13 models

Online tool 8 models
Table 4 Characteristics of the models (Continued)

\begin{tabular}{ll}
\hline & Number of models ${ }^{a}$ \\
\hline Decision tree & 5 models \\
Somogram & 4 models \\
No report & 1 model \\
Number of risk groups & 27 models \\
5 & \\
4 & 3 models \\
3 & 3 models \\
2 & 9 models \\
No report/No risk group & 6 models \\
Validation & 33 models \\
No validation & 11 models \\
Internal validation & 43 models \\
External validation & 17 models
\end{tabular}

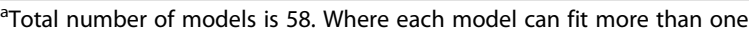
category, the number of models may not always total 58

We found that most studies were at moderate or low risk of bias, which contrasts with the findings in other systematic reviews that most studies were at poor quality $[11,77]$. However, the previous reviews did not report the detailed quality assessment of each study.

Most studies included in this review used a retrospective design, and therefore had issues related to missing data and a lack of consistency in predictor and outcome measurement $[9,11,77]$. Prospective cohort studies have been suggested as the best design for predictive modelling because they enable not only clear and consistent definitions but also prospective measurement of predictors and outcomes $[3,9]$.

Similar to the previous systematic reviews $[8,77,80,81]$, we found that most studies (59\%) did not report, or did not satisfy the suggested minimum requirements for the numbers of events, i.e., 10 events per candidate variable for model development studies, and 100 events for model validation studies [11, 82-87]. A small number of events could mislead the results of validation measures, for example, misleadingly high value of the C-index [85].

We found that the most commonly used prognostic factors in the models were nodal status, tumour size, and tumour grade, followed by age at diagnosis and ER status, as reported in other reviews $[11,88]$. The NPI was one of the simplest and oldest models, and included only nodal status, tumour size, and tumour grade. There are several attempts to improve the prognostic values of the NPI by adding other novel predictors, such as age at diagnosis [89], hormonal receptor status [37, 89, 90], and HER2 status [37, 55, 90, 91]. However, such modification has not been proven to be better than the NPI in 
independent populations. Future research may evaluate the added prognostic value of other important variables to the NPI and other models.

The use of gene expression or novel biomolecular factors is increasing due to their potential to provide molecular phenotyping that recognises distinct tumour categorisations not evident by traditional factors [92, 93]. However, we excluded models based on genetic profiles or novel biomolecular factors because these factors are not yet widely adopted in clinical practice. Additionally, since models that include both genetic and traditional factors are suggested to be superior to those based on either set of features alone $[94,95]$, studies of the prognostic value of any new marker should look at the extra benefit of including it when traditional clinico-pathological variables are also included.

The most commonly used method for model development was Cox PH regressions as reported in other reviews $[11,96]$. Cox PH regressions are simple but have been criticised because the PH assumption may not always hold, since the strengths of prognostic factors change over time in the "real world" $[19,29,97]$. To address this, alternative methods such as artificial neural networks, support vector machines, or multistate models have been applied. These models may perform better than Cox $\mathrm{PH}$ models but have not been validated in independent populations, limiting generalisability [22-24, 26]. Furthermore, clinical validity is more important than statistical validity [11]. As the models developed based on Cox $\mathrm{PH}$ regressions, such as the NPI or PREDICT, showed good performance in many populations, Cox $\mathrm{PH}$ regressions will still dominate the literature on model development methods.

Differences in the methodological issues pointed out in our review may be explained by differences in the purpose of developing the model (e.g., to support clinical decision making, to evaluate the prognostic value of a specific factor, or to compare statistical methods used to develop the model). However, not many developers explicitly stated the purposes of their models. Nevertheless, the models that have gone to further external validation were developed mainly to support clinical decision making. These models were considered useful in clinical practice.

Only one of 49 external validation studies in our review tested "clinical usefulness", which was defined by the authors as the ability for a model to classify patients into low risk and high risk groups better than without that model, and the measure used was accuracy rate [98]. However, a model's ability to classify patients into two risk groups may not reflect its usefulness in clinical settings. A prognostic model can be useful if it classifies patients into more than two risk groups to influence therapy or to save patients from unnecessary treatments or to estimate survival time for patients [8]. Future research may consider more relevant measures to assess clinical usefulness such as the improvement of clinical decision making when applying a model, patients' insights about model reports, or how doctors communicate with patients about model results.

Previous reviews reported that Hosmer-Lemeshow goodness-of-fit test was used most frequently to test the deviations in calibration plots $[77,81]$ but we found that the difference between the predicted and observed outcomes was more commonly used (Table 6). Steyerberg and Vergouwe (2014) did not recommend the Hosmer-Lemeshow goodness-of-fit test because it only provides a $p$-value instead of providing the direction and magnitude of miscalibration [99]. This test has also been criticised for being arbitrary and imprecise as the p-value is dependent on miscalibration and sample size [99]. Instead, Steyerberg and Vergouwe (2014) advocated the use of the intercept of the calibration plot, also called calibration-in-the-large [99], which is closely related to the difference between the predicted and observed outcomes, either absolute or relative difference [100].

We found that C-index/AUC was the most commonly used method to assess discrimination, followed by Kaplan-Meier curves and log-rank tests, as reported in previous systematic reviews in several clinical fields $[9,77,96]$. Log-rank tests were not recommended because they do not give an estimate of the magnitude of the separation of the risk groups [96]. In contrast, C-index, or AUC for a binary endpoint, was advocated by several authors [99].

This review focused on models that have been externally validated in several settings by independent researchers for many reasons. Firstly, external validation is preferable to internal validation to test a model's transportability as the case-mix (or the distribution of predictors) in an independent population is unlikely to be identical with that in the model development population [85]. Secondly, to enhance the generalisability of a model, it should ideally be validated in different settings with diversity of case-mixes [85]. A model with good performance in diverse settings is more likely to be generalisable to a plausibly related, but untested population $[13,85,86]$. Finally, a reliable model should be tested by independent researchers in different settings [8, 101]. If model development and external validation are undertaken by the same researchers, there may be a temptation to revise the model to fit the external validation data [8]. A clear distinction between the external validation studies conducted by independent researchers and by model developers should be made to reduce inflated findings and "spin" [102-104].

The studies that compared Adjuvant!, CancerMath, PREDICT v1.3, and the NPI in independent datasets by independent researchers did not find the superiority of one model over the others. When they were validated 
Table 5 Risk of bias within the external validation studies by models

\begin{tabular}{|c|c|c|c|c|c|c|c|}
\hline \multirow[t]{2}{*}{ No } & \multirow[t]{2}{*}{ Model } & \multirow[t]{2}{*}{ Validated by } & \multirow{2}{*}{$\begin{array}{l}\text { Authors(Year of } \\
\text { publication) }\end{array}$} & \multicolumn{4}{|c|}{ Risk of bias domain } \\
\hline & & & & $\begin{array}{l}\text { Study } \\
\text { Participation }\end{array}$ & $\begin{array}{l}\text { Prognostic Factor } \\
\text { Measurement }\end{array}$ & $\begin{array}{l}\text { Outcome } \\
\text { Measurement }\end{array}$ & $\begin{array}{l}\text { Statistical Analysis } \\
\text { and Presentation }\end{array}$ \\
\hline \multirow[t]{17}{*}{$\overline{1}$} & \multirow[t]{17}{*}{ Adjuvant! } & \multirow[t]{4}{*}{ Model developer(s) } & Mook et al. (2009) [64] & Low & Moderate & Moderate & Low \\
\hline & & & Olivotto et al. (2005) [45] & Low & High & Low & Low \\
\hline & & & Wishart et al. (2011) [46] & Low & High & Low & Low \\
\hline & & & Wishart et al. (2012) [35] & Low & High & Low & Low \\
\hline & & \multirow{13}{*}{$\begin{array}{l}\text { Independent } \\
\text { researcher(s) }\end{array}$} & Campbell et al. (2009) [59] & Low & Moderate & Low & Low \\
\hline & & & Hajage et al. (2011) [58] & Moderate & Low & Moderate & Low \\
\hline & & & Hearne et al. (2015) [47] & Low & Low & Low & Low \\
\hline & & & M. Jung et al. (2013) [44] & Low & Moderate & Moderate & Low \\
\hline & & & Laas et al. (2015) [68] & Moderate & Moderate & Moderate & Low \\
\hline & & & Lende et al. (2010) [136] & Low & Moderate & Low & Low \\
\hline & & & Plakhins et al. (2013) [63] & Moderate & Moderate & Low & Low \\
\hline & & & Quintyne et al. (2013) [60] & Low & Moderate & Moderate & Low \\
\hline & & & Rejali et al. (2015) [54] & Moderate & Moderate & Moderate & Low \\
\hline & & & de Glas et al. (2014) [66] & Low & Moderate & Low & Low \\
\hline & & & Bhoo-Pathy et al. (2012) [61] & Low & Moderate & Moderate & Low \\
\hline & & & Kuo et al. (2012) [62] & Low & Low & Moderate & Low \\
\hline & & & $\begin{array}{l}\text { Mojir Sheibani et al. (2013) } \\
\text { [65] }\end{array}$ & Low & Low & Moderate & Low \\
\hline \multirow[t]{15}{*}{2} & \multirow[t]{15}{*}{ NPI } & Model developer(s) & van Belle et al. (2010a) [73] & Low & Moderate & Low & Low \\
\hline & & \multirow{14}{*}{$\begin{array}{l}\text { Independent } \\
\text { researcher(s) }\end{array}$} & Albergaria et al. (2011) [75] & Moderate & Moderate & Low & Low \\
\hline & & & Balslev et al. (1994) [48] & Low & High & Low & Low \\
\hline & & & Chollet et al. (2003) [49] & Moderate & High & Low & Low \\
\hline & & & D'Eredita et al. (2001) [51] & Low & Low & Low & Low \\
\hline & & & Hearne et al. (2015) [47] & Low & Low & Low & Low \\
\hline & & & M. Liu et al. (2010) [74] & Low & Moderate & Low & Low \\
\hline & & & Megha et al. (2010) [70] & Moderate & Moderate & Low & Low \\
\hline & & & Okugawa et al. (2009) [52] & Low & Low & Low & Low \\
\hline & & & Quintyne et al. (2013) [60] & Low & Moderate & Moderate & Low \\
\hline & & & Rejali et al. (2015) [54] & Moderate & Moderate & Moderate & Low \\
\hline & & & Sidoni et al. (2004) [71] & Moderate & Low & Low & Low \\
\hline & & & Sundquist et al. (1999) [72] & Low & Moderate & Low & Low \\
\hline & & & van Belle et al. (2010b) [37] & Low & High & Low & Low \\
\hline & & & Yadav et al. (2015) [50] & Moderate & Moderate & Low & High \\
\hline \multirow[t]{5}{*}{3} & \multirow[t]{5}{*}{ PREDICT v1.3 } & Model developer(s) & Wishart et al. (2014) [36] & Low & Moderate & Low & Low \\
\hline & & \multirow{4}{*}{$\begin{array}{l}\text { Independent } \\
\text { researcher(s) }\end{array}$} & de Glas et al. (2016) [69] & Low & Moderate & Low & Low \\
\hline & & & Laas et al. (2015) [68] & Moderate & Moderate & Moderate & Low \\
\hline & & & Plakhins et al. (2013) [63] & Moderate & Moderate & Low & Low \\
\hline & & & Wong et al. (2015) [67] & Low & Moderate & Low & Low \\
\hline \multirow[t]{3}{*}{4} & \multirow[t]{3}{*}{ Cancer Math } & Model developer(s) & Michaelson et al. (2011) [42] & Low & High & Low & Moderate \\
\hline & & Independent & Laas et al. (2015) [68] & Moderate & Moderate & Moderate & Low \\
\hline & & res & Miao et al. (2016) [138] & Moderate & High & Low & Low \\
\hline \multirow[t]{2}{*}{5} & \multirow[t]{2}{*}{ MPI } & \multirow{2}{*}{$\begin{array}{l}\text { Independent } \\
\text { researcher(s) }\end{array}$} & Aaltomaa et al. (1983) [130] & Low & Low & Low & Low \\
\hline & & & Carbone et al. (1999) [132] & Moderate & Low & Low & Low \\
\hline
\end{tabular}


Table 5 Risk of bias within the external validation studies by models (Continued)

\begin{tabular}{|c|c|c|c|c|c|c|c|}
\hline \multirow[t]{2}{*}{ No } & \multirow[t]{2}{*}{ Model } & \multirow[t]{2}{*}{ Validated by } & \multirow{2}{*}{$\begin{array}{l}\text { Authors(Year of } \\
\text { publication) }\end{array}$} & \multicolumn{4}{|c|}{ Risk of bias domain } \\
\hline & & & & $\begin{array}{l}\text { Study } \\
\text { Participation }\end{array}$ & $\begin{array}{l}\text { Prognostic Factor } \\
\text { Measurement }\end{array}$ & $\begin{array}{l}\text { Outcome } \\
\text { Measurement }\end{array}$ & $\begin{array}{l}\text { Statistical Analysis } \\
\text { and Presentation }\end{array}$ \\
\hline & & & Collan et al. (1998) [98] & Moderate & Low & Low & Low \\
\hline \multirow[t]{3}{*}{6} & \multirow[t]{3}{*}{ IBTR!2.0 } & Model developer(s) & Sanghani et al. (2010) [38] & Moderate & Moderate & Moderate & Low \\
\hline & & \multirow{2}{*}{$\begin{array}{l}\text { Independent } \\
\text { researcher(s) }\end{array}$} & S.P. Jung et al. (2013) [134] & Low & Moderate & Low & Low \\
\hline & & & Kindts et al. (2016) [135] & Moderate & Moderate & Moderate & Low \\
\hline 7 & $\begin{array}{l}\text { Paik et al. } \\
\text { (1990) }\end{array}$ & $\begin{array}{l}\text { Independent } \\
\text { researcher(s) }\end{array}$ & Ribelles et al. (1997) [139] & Moderate & Low & Low & Low \\
\hline 8 & $\begin{array}{l}\text { Lovekin et al. } \\
\text { (1991) }\end{array}$ & $\begin{array}{l}\text { Independent } \\
\text { researcher(s) }\end{array}$ & Ribelles et al. (1997) [139] & Moderate & Low & Low & Low \\
\hline \multirow[t]{3}{*}{9} & \multirow[t]{3}{*}{ PREDICT 1.1} & \multirow[t]{3}{*}{ Model developer(s) } & Wishart et al. (2010b) [40] & Low & High & Low & Low \\
\hline & & & Wishart et al. (2011) [46] & Low & High & Low & Low \\
\hline & & & Wishart et al. (2012) [35] & Low & High & Low & Low \\
\hline \multirow[t]{3}{*}{10} & \multirow[t]{3}{*}{ PREDICT V1.2 } & \multirow[t]{3}{*}{ Model developer(s) } & Maishman et al. (2015) [137] & Moderate & Moderate & Low & Low \\
\hline & & & Wishart et al. (2014) [36] & Low & Moderate & Low & Low \\
\hline & & & Wishart et al. (2012) [35] & Low & High & Low & Low \\
\hline 11 & iNPI & Model developer(s) & van Belle et al. (2010a) [73] & Low & Moderate & Low & Low \\
\hline 12 & $\mathrm{NPI}+$ & Model developer(s) & Green et al. (2016) [133] & Low & Moderate & Low & Low \\
\hline 13 & INFLUENCE & Model developer(s) & Witteveen et al. (2015) [39] & Low & Moderate & High & Low \\
\hline 14 & OPTIONS & Model developer(s) & Campbell et al. (2010) [19] & Moderate & Low & Moderate & Moderate \\
\hline 15 & Chen et al. (2016) & Model developer(s) & Chen et al. (2016) [41] & Low & High & Low & Low \\
\hline 16 & $\begin{array}{l}\text { de Laurentiis et al. } \\
\text { (1999) }\end{array}$ & Model developer(s) & de Laurentiis et al. (1999) [43] & Moderate & Low & Moderate & Moderate \\
\hline 17 & Bryan et al. (1986) & Model developer(s) & Alexander et al. (1987) [131] & Low & Low & Low & Low \\
\hline
\end{tabular}

Total number of validation studies is 49 . Since some studies validated more than one model, the number of studies does not total 49

individually, only the NPI performed well in most independent populations, whereas the other models were accurate in just some populations. The NPI has been advocated by several authors and is one of the few models that are used in clinical practice [11]. The advantage of the NPI is its simplicity, which is an important criterion in developing a useful model [105]. Additionally, the model shows good reducibility and transportability because it performed well in diverse settings when validated by independent researchers. The model has good discrimination in most populations, and is therefore clinically useful because it classifies patients into risk groups to influence therapy or save patients from unnecessary treatments $[8,11]$. However, most studies that validated the NPI only assessed its discrimination but not calibration, because the model cannot estimate prognosis of individual patients. Some studies assigned OS for all patients in the same NPI group based on previous reports $[47,54,73]$. This practice is criticised as inappropriate, since estimates based on data at a period in the past are probably not well calibrated for patients today. Advanced treatments, such as hormonal therapies or targeted therapies, in addition to improvement in detection and diagnosis, may improve the survival within the NPI groups [106]. Regular updates would be required for better prediction of prognosis for each group.

The performance of a particular model may vary across different populations. For example, the NPI, a UK-based model, performed well in most countries in Europe (Italy, Sweden, Denmark, Belgium, Norway), and even in Asia (Japan, India), but was less accurate in Irish patients. The US-based model Adjuvant! showed good performance in a large Dutch population, but poor performance in patients from the UK or Asia (Malaysia, South Korea, Taiwan). Therefore, a reliable validation study should be conducted before a model is applied in other populations.

Most studies in our review showed that models were less accurate in patients aged under 40 years or over 65 years, although some studies showed opposite results. Likewise, a previous review concluded that Adjuvant! was less accurate in young and elderly patients in most studies [14]. However, most validation studies lack generalisability because they were based on small numbers of events or did not report the numbers of events. Only a few studies with appropriate numbers of events were 
Table 6 Validation methods

\begin{tabular}{|c|c|c|c|c|}
\hline \multirow{2}{*}{\multicolumn{2}{|c|}{$\frac{\text { Domain } \quad \text { Measure }}{\text { Overall performance }}$}} & Description & Internal validation & External validation \\
\hline & & $\begin{array}{l}\text { Measuring the distance between the predicted a } \\
\text { nd actual outcomes [9] }\end{array}$ & 3 studies & 2 studies \\
\hline & $\mathrm{R}^{2}$ & $\begin{array}{l}\text { The amount of variability in outcomes that is } \\
\text { explained by the model [9] }\end{array}$ & 1 study & 1 study \\
\hline & Brier score & $\begin{array}{l}\text { A measure of the average discrepancy between } \\
\text { the true disease status and the predicted } \\
\text { probability of developing the disease [85] }\end{array}$ & 2 studies & 1 study \\
\hline \multirow[t]{6}{*}{ Calibratic } & & $\begin{array}{l}\text { The level of agreement between the observed } \\
\text { and predicted outcomes [9] }\end{array}$ & 12 studies & 32 studies \\
\hline & Calibration plot & $\begin{array}{l}\text { Having predictions on the } x \text { axis, and the observed } \\
\text { outcome on the } y \text { axis [9] }\end{array}$ & 7 studies & 20 studies \\
\hline & SMR (Standardised mortality ratio) & $\begin{array}{l}\text { The difference from the predicted calibration line } \\
\text { and the ideal line in calibration plot [69] }\end{array}$ & 0 study & 1 study \\
\hline & $E / O$ & $\begin{array}{l}\text { Ratio between the predicted and observed } \\
\text { outcomes [100] }\end{array}$ & 3 studies & 2 studies \\
\hline & $\mathrm{E}-\mathrm{O}$ & $\begin{array}{l}\text { Absolute difference between the predicted and } \\
\text { observed outcomes }\end{array}$ & 2 studies & 28 studies \\
\hline & $\begin{array}{l}\text { Hosmer-Lemeshow goodness- } \\
\text { of-fit test }\end{array}$ & The ability of a model to fit a given set of data [9] & 4 studies & 5 studies \\
\hline \multirow[t]{6}{*}{ Discrimi } & & $\begin{array}{l}\text { The extent to which the model can discriminate } \\
\text { patients with the outcome and those without } \\
\text { the outcome [9] }\end{array}$ & 28 studies & 37 studies \\
\hline & Kaplan-Meier curve & $\begin{array}{l}\text { The probability of surviving in a given length of } \\
\text { time while considering time in many small intervals } \\
\text { [140] }\end{array}$ & 23 studies & 20 studies \\
\hline & Log-rank test & $\begin{array}{l}\text { Testing the null hypothesis that there is no } \\
\text { difference between populations in the probability } \\
\text { of an event at any time point [141] }\end{array}$ & 16 studies & 18 studies \\
\hline & C-index & $\begin{array}{l}\text { The probability that, for a randomly chosen pair of } \\
\text { patients, the one who actually experienced the } \\
\text { event of interest has a higher predicted value than } \\
\text { the one who has not experienced the event [85] }\end{array}$ & 11 studies & 12 studies \\
\hline & $A \cup C$ & $\begin{array}{l}\text { Area under the receiving operating characteristic } \\
\text { curve is identical to C-index for a model with binary } \\
\text { outcome [9] }\end{array}$ & 11 studies & 12 studies \\
\hline & CPE & $\begin{array}{l}\text { Concordance probability estimate represents the } \\
\text { pairwise probability of lower patient risk given } \\
\text { longer survival time [142] }\end{array}$ & 0 study & 1 study \\
\hline \multicolumn{2}{|c|}{ Clinical usefulness } & $\begin{array}{l}\text { The ability to make better decisions with a } \\
\text { model than without it [9] }\end{array}$ & 13 studies & 1 study \\
\hline & Accuracy rate & $=\frac{\text { true negative }+ \text { true positive }}{\text { Total patients }}[9]$ & 11 studies & 1 study \\
\hline & Sensitivity & $\begin{array}{l}\text { The fraction of true-positive classifications among } \\
\text { the total number of patients with the outcome [9] }\end{array}$ & 9 studies & 1 study \\
\hline & Specificity & $\begin{array}{l}\text { The fraction of true negative classifications among } \\
\text { the total number of patients without the } \\
\text { outcome [9] }\end{array}$ & 8 studies & 1 study \\
\hline & Positive predictive value (PPV) & $=\frac{\text { number of true positives }}{\text { number of positives calls }}$ & 1 study & 0 study \\
\hline & Negative predictive value (NPV) & $=\frac{\text { number of true negatives }}{\text { number of negative callss }}$ & 1 study & 0 study \\
\hline \multicolumn{2}{|c|}{ Agreement } & $\begin{array}{l}\text { Measure the agreement when comparing } \\
\text { two models }\end{array}$ & 0 study & 4 studies \\
\hline & Kappa coefficient (K) & $\begin{array}{l}\text { Measuring the inter-rater agreement for } \\
\text { qualitative items. }\end{array}$ & 0 study & 1 study \\
\hline & $\begin{array}{l}\text { Correlation coefficient (Pearson } \\
\text { or Spearman) }\end{array}$ & $\begin{array}{l}\text { Measuring how strong a pair of variables is } \\
\text { related }\end{array}$ & 0 study & 3 studies \\
\hline \multirow[t]{3}{*}{ Others } & Shrinkage factor & Cross-validated prognostic index [143] & 2 studies & 0 study \\
\hline & Univariate analysis & $\begin{array}{l}\text { Examining the distribution of cases in only one variable } \\
\text { at a time }\end{array}$ & 2 studies & 10 studies \\
\hline & Multivariate analysis & Examining more than two variables simultaneously & 3 studies & 6 studies \\
\hline
\end{tabular}


designed to assess models' performance in young and elderly patients only. These studies found that PREDICT v1.3 was less accurate in predicting 10-year OS [69], whereas Adjuvant! overpredicted 10-year OS and event-free survival (EFS) in Dutch elderly patients [66]. Nonetheless, it is difficult to know if the poor performance of models in young and elderly patients was attributable to age only, or to other effect modifiers such as ethnicity.

\section{Conclusion}

We reviewed the development and/or validation of 58 models predicting mortality and/or recurrence for female breast cancer. These models varied in terms of methods of development and/or validation, predictors, outcomes, and patients included. Most models have been developed in Europe, Asia, and North America. We found that models performed well in internal validation cohorts, but the results were unpredictable in external validation cohorts, especially in young and elderly patients, and in high risk patients. NPI is an exception, which performed well in most independent populations. Therefore, models should be validated before being applied in another population.

\section{Additional files}

Additional file 1: Search terms. (XLSX $10 \mathrm{~kb}$ )

Additional file 2: Model development studies that were excluded because of no full text. (XLSX $13 \mathrm{~kb}$ )

Additional file 3: Model validation studies that were excluded because of no full text. (XLSX $12 \mathrm{~kb}$ )

Additional file 4: Articles that presented model development and/or internal validation. (XLSX $47 \mathrm{~kb}$ )

Additional file 5: Articles that presented only the internal validation. (XLSX $12 \mathrm{~kb}$ )

Additional file 6: Articles that presented model external validation. (XLSX $39 \mathrm{~kb}$ )

Additional file 7: Number of external validation studies. (XLSX $10 \mathrm{~kb}$ ) Additional file 8: Characteristics of the models validated in external populations. (XLSX $11 \mathrm{~kb}$ )

Additional file 9: Overview of external validation studies. (XLSX $16 \mathrm{~kb}$ )

Additional file 10: Studies that compared models by independent researchers. (XLSX $10 \mathrm{~kb})$

Additional file 11: Studies that compared models by models' developers. (XLSX $9 \mathrm{~kb})$

\section{Abbreviations}

Adjuvant! : Adjuvant!Online; AIC: Akaike information criterion; AUC : Area under the curve; BCSS : Breast cancer-specific survival; BIC: Bayesian information criterion; $\mathrm{Cox} \mathrm{PH}$ regression : Cox proportional hazards regression; CPE: Concordance probability estimate; DFS : Disease-free survival; EFS : Event-free survival; ER : Oestrogen receptor; HER2 : Human epidermal growth factor receptor 2; IBTR : Ipsilateral breast tumour recurrence; LRR : Local-regional recurrence; MAI : Mitotic Activity Index; MPI : Morphometric Prognostic Index; NPI : Nottingham Prognostic Index; NPV: Negative predictive value; OS : Overall survival; PPV: Positive predictive value; PR : Progesterone receptor; QUIPS : QUality In Prognosis Studies; RCT
}

: Randomised controlled trial; RFS : Relapse-free survival; ROC : Receiver operating characteristic; SD : Standard deviation; SE: Standard error: SMR: Standardised mortality ratio; The UK: The United Kingdom; The USA: The United States of America; TNM : Tumour, Node, and Metastasis

\section{Acknowledgements}

We thank the New Zealand Aid Programme for funding MP to pursue his Master of Public Health at the University of Auckland. This study is a part of his Master's thesis.

\section{Funding}

The research received no specific grant from any funding agency in the public, commercial, or non-for-profit sectors.

\section{Availability of data and materials}

The datasets supporting the conclusions of this article are included within the article and its additional files.

\section{Authors' contributions}

ME and ST developed the concept. MP, ST, and ME designed the study, searched the publications and reviewed the articles. All authors contributed to the interpretation of the data and to drafts of the report and reviewed and approved the submission.

Ethics approval and consent to participate

Not applicable

\section{Consent for publication}

Not applicable

\section{Competing interests}

The authors declare that they have no competing interests.

\section{Publisher's Note}

Springer Nature remains neutral with regard to jurisdictional claims in published maps and institutional affiliations.

Received: 28 August 2018 Accepted: 6 March 2019

Published online: 14 March 2019

\section{References}

1. Coleman MP, Quaresma M, Berrino F, Lutz J, de Angelis R, Capocaccia R, Baili P, Rachet B, Gatta G, Hakulinen T. Cancer survival in five continents: a worldwide population-based study (CONCORD). Lancet Oncol. 2008;9(8): 730-56.

2. Polyak K. Heterogeneity in breast cancer. J Clin Invest. 2011;121(10):3786-8.

3. Moons KG, Royston P, Vergouwe Y, Grobbee DE, Altman DG. Prognosis and prognostic research: what, why, and how? BMJ. 2009;338:b375.

4. Buchholz TA, Strom EA, McNeese MD. In: Cox JD, Ang KK, editors. The breast. In Radiation oncology: Rationale, technique, results. St. Louis, Missouri: Mosby; 2003. p. 333-86.

5. Blamey R, Ellis I, Pinder S, Lee A, Macmillan R, Morgan D, Robertson J, Mitchell M, Ball G, Haybittle J. Survival of invasive breast cancer according to the Nottingham prognostic index in cases diagnosed in 1990-1999. Eur J Cancer. 2007;43(10):1548-55.

6. Hagerty RG, Butow PN, Ellis PA, Lobb EA, Pendlebury S, Leighl N, Goldstein D, Lo SK, Tattersall MH. Cancer patient preferences for communication of prognosis in the metastatic setting. J Clin Oncol. 2004:22(9):1721-30.

7. Lobb EA, Kenny DT, Butow PN, Tattersall MH. Women's preferences for discussion of prognosis in early breast cancer. Health Expect. 2001;4(1): 48-57.

8. Altman $D G$, Royston P. What do we mean by validating a prognostic model? Stat Med. 2000;19(4):453-73.

9. Steyerberg EW. Clinical prediction models: a practical approach to development, validation, and updating. New York: Springer Science \& Business Media; 2008.

10. Eskelinen M, Lipponen P, Papinaho S, Aaltomaa S, Kosma VM, Klemi P, Syrjanen K. DNA flow-cytometry, nuclear morphometry, mitotic indexes and steroid-receptors as independent prognostic factors in female breast cancer. Int J Cancer. 1992;51(4):555-61. 
11. Altman DG. Prognostic models: a methodological framework and review of models for breast cancer. Cancer Investig. 2009;27(3):235-43.

12. Clark GM. Do we really need prognostic factors for breast cancer? Breast Cancer Res Treat. 1994;30(2):117-26.

13. Justice AC, Covinsky KE, Berlin JA. Assessing the generalisability of prognostic information. Ann Intern Med. 1999;130(6):515-24.

14. Engelhardt EG, Garvelink MM, de Haes JH, Van der Hoeven JJ, Smets EM, Pieterse $\mathrm{AH}$, Stiggelbout AM. Predicting and communicating the risk of recurrence and death in women with early-stage breast cancer: a systematic review of risk prediction models. J Clin Oncol. 2013;32(3):238-50.

15. Collins GS, Reitsma JB, Altman DG, Moons KGM. Transparent reporting of a multivariable prediction model for individual prognosis or diagnosis (TRIPOD): the TRIPOD statement. BMC Med. 2015;13(1):1.

16. Moons KG, de Groot JAH, Bouwmeester W, Vergouwe $Y$, Mallett S, Altman DG, Reitsma JB, Collins GS. Critical appraisal and data extraction for systematic reviews of prediction modelling studies: the CHARMS checklist. PLoS Med. 2014;11(10):e1001744.

17. Hayden JA, Van der Windt DA, Cartwright JL, Côté P, Bombardier C. Assessing bias in studies of prognostic factors. Ann Intern Med. 2013;158(4):280-6.

18. Hayden JA, Côté $P$, Bombardier C. Evaluation of the quality of prognosis studies in systematic reviews. Ann Intern Med. 2006;144(6):427-37.

19. Campbell HE, Gray AM, Harris AL, Briggs AH, Taylor MA. Estimation and external validation of a new prognostic model for predicting recurrencefree survival for early breast cancer patients in the UK. Br J Cancer. 2010; 103(6):776-86

20. Chao CM, Yu YW, Cheng BW, Kuo YL. Construction the model on the breast cancer survival analysis use support vector machine, logistic regression and decision tree. J Med Syst. 2014;38:106.

21. Fleming ST, Rastogi A, Dmitrienko A, Johnson KD. A comprehensive prognostic index to predict survival based on multiple comorbidities: a focus on breast cancer. Med Care. 1999;37(6):601-14.

22. Kim W, Kim KS, Lee JE, Noh DY, Kim SW, Jung YS, Park MY, Park RW. Development of novel breast cancer recurrence prediction model using support vector machine. J Breast Cancer. 2012;15(2):230-8.

23. Lisboa PJG, Wong H, Harris P, Swindell R. A Bayesian neural network approach for modelling censored data with an application to prognosis after surgery for breast cancer. Artif Intell Med. 2003;28(1):1-25.

24. Ture M, Tokatli F, Omurlu IK. The comparisons of prognostic indexes using data mining techniques and cox regression analysis in the breast cancer data. Expert Syst Appl. 2009;36(4):8247-54.

25. Choi JP, Han TH, Park RW. A hybrid Bayesian network model for predicting breast cancer prognosis. J Kor Soc Med Informatics. 2009;15(1):49-57.

26. Jerez JM, Franco L, Alba E, Llombart-Cussac A, Lluch A, Ribelles N, Munarriz B, Martin M. Improvement of breast cancer relapse prediction in high risk intervals using artificial neural networks. Breast Cancer Res Treat. 2005;94(3): 265-72.

27. Delen D, Walker G, Kadam A. Predicting breast cancer survivability: a comparison of three data mining methods. Artif Intell Med. 2005;34(2):113-27.

28. Tokatli ZF, Ture M, Kurt Omurlu I, Csar Alas R, Uzal MC. Developing and comparing two different prognostic indexes for predicting disease-free survival of nonmetastatic breast cancer patients. Turkish J Med Sci. 2011; 41(5):769-80.

29. Ripley RM, Harris AL, Tarassenko L. Neural network models for breast cancer prognosis. Neural Comput Applic. 1998;7(4):367-75.

30. Cheng SH, Horng CF, Clarke JL, Tsou MH, Tsai SY, Chen CM, Jian JJ, Liu MC, West M, Huang AT, Prosnitz LR. Prognostic index score and clinical prediction model of local regional recurrence after mastectomy in breast cancer patients. Int J Radiat Oncol Biol Phys. 2006;64(5):1401-9.

31. Kollias J, Murphy CA, Elston CW, Ellis IO, Robertson JFR, Blamey RW. The prognosis of small primary breast cancers. Eur J Cancer. 1999;35(6):908-12.

32. Galea MH, Blamey RW, Elston CE, Ellis IO. The Nottingham prognostic index in primary breast cancer. Breast Cancer Res Treat. 1992;22(3):207-19.

33. Todd JH, Dowle C, Williams MR, Elston CW, Ellis IO, Hinton CP, Blamey RW, Haybittle JL. Confirmation of a prognostic index in primary breast cancer. Br J Cancer. 1987:56(4):489-92.

34. van Diest PJ, Baak JP. The morphometric prognostic index is the strongest prognosticator in premenopausal lymph node-negative and lymph nodepositive breast cancer patients. Hum Pathol. 1991;22(4):326-30.

35. Wishart GC, Bajdik CD, Dicks E, Provenzano E, Schmidt MK, Sherman M, Greenberg DC, Green AR, Gelmon KA, Kosma VM, Olson JE, Beckmann MW, Winqvist R, Cross SS, Severi G, Huntsman D, Pylkas K, Ellis I, Nielsen TO, Giles
G, Blomqvist C, Fasching PA, Couch FJ, Rakha E, Foulkes WD, Blows FM, Begin LR, van't Veer $L$, Southey M, Nevanlinna H, Mannermaa A, Cox A, Cheang M, Baglietto L, Caldas C, Garcia-Closas M, PDP P. PREDICT Plus: Development and validation of a prognostic model for early breast cancer that includes HER2. Br J Cancer. 2012;107(5):800-7.

36. Wishart GC, Rakha E, Green A, Ellis I, Ali HR, Provenzano E, Blows FM, Caldas C, Pharoah PDP. Inclusion of Ki67 significantly improves performance of the PREDICT prognostication and prediction model for early breast cancer. Eur J Surg Oncol. 2014;40(5):607.

37. van Belle V, van Calster B, Brouckaert O, Bempt IV, Pintens S, Harvey V, Murray P, Naume B, Wiedswang G, Paridaens R, Moerman P, Amant F, Leunen K, Smeets A, Drijkoningen M, Wildiers H, Christiaens M, Vergote I, Van Huffel S, Neven P. Qualitative assessment of the progesterone receptor and HER2 improves the Nottingham prognostic index up to 5 years after breast Cancer diagnosis. J Clin Oncol. 2010;28(27):4129-34.

38. Sanghani M, Truong PT, Raad RA, Niemierko A, Lesperance M, Olivotto IA, Wazer DE, Taghian AG. Validation of a web-based predictive nomogram for ipsilateral breast tumour recurrence after breast conserving therapy. J Clin Oncol. 2010;28(5):718-22.

39. Witteveen A, Vliegen IMH, Sonke GS, Klaase JM, Jzerman MJ, Siesling S. Personalisation of breast cancer follow-up: a time-dependent prognostic nomogram for the estimation of annual risk of locoregional recurrence in early breast cancer patients. Breast Cancer Res Treat. 2015;152(3):627-36.

40. Wishart GC, Azzato EM, Greenberg DC, Rashbass J, Kearins O, Lawrence G, Caldas C, Pharoah PDP. PREDICT: a new UK prognostic model that predicts survival following surgery for invasive breast cancer. Breast Cancer Res. 2010;12:R1.

41. Chen YC, Lai HW, Wang WC, Kuo YL. Validation of breast Cancer survival prediction model with SEER database. J Integr Oncol. 2016;5(3):174

42. Michaelson JS, Chen LL, Bush D, Fong A, Smith B, Younger J. Improved web-based calculators for predicting breast carcinoma outcomes. Breast Cancer Res Treat. 2011;128(3):827-35.

43. de Laurentiis M, de Placido S, Bianco AR, Clark GM, Ravdin PM. A prognostic model that makes quantitative estimates of probability of relapse for breast cancer patients. Clin Cancer Res. 1999:5(12):4133-9.

44. Jung M, Choi EH, Nam CM, Rha SY, Jeung HC, Lee SH, Yang WI, Roh JK, Chung HC. Application of the adjuvant!Online model to Korean breast cancer patients: an assessment of prognostic accuracy and development of an alternative prognostic tool. Ann Surg Oncol. 2013;20(8):2615-24.

45. Olivotto IA, Bajdik CD, Ravdin PM, Speers CH, Coldman AJ, Norris BD, Davis GJ, Chia SK, Gelmon KA. Population-based validation of the prognostic model adjuvant! For early breast cancer. J Clin Oncol. 2005;23(12):2716-25.

46. Wishart GC, Bajdik CD, Azzato EM, Dicks E, Greenberg DC, Rashbass J, Caldas C, Pharoah PDP. A population-based validation of the prognostic model PREDICT for early breast cancer. Eur J Surg Oncol. 2011;37(5):411-7.

47. Hearne BJ, Teare MD, Butt M, Donaldson L. Comparison of Nottingham prognostic index and adjuvant!Online prognostic tools in young women with breast cancer: review of a single-institution experience. BMJ Open. 2015;5(1):e005576

48. Balslev I, Axelsson CK, Zedeler K, Rasmussen BB, Carstensen B, Mouridsen HT. The Nottingham prognostic index applied to 9,149 patients from the studies of the Danish breast Cancer cooperative group (DBCG). Breast Cancer Res Treat. 1994;32(3):281-90.

49. Chollet $\mathrm{P}$, Amat $\mathrm{S}$, Belembaogo E, Cure H, de Latour M, Dauplat J, Le Bouedec G, Mouret-Reynier MA, Ferriere JP, Penault-Llorca F. Is Nottingham prognostic index useful after induction chemotherapy in operable breast cancer? Br J Cancer. 2003;89(7):1185-91.

50. Yadav R, Sen R, Chauhan P. Calculation of NPI score: prognosis of breast cancer. Indian J Public Health Res Dev. 2015:6(2):199-202.

51. D'Eredita G, Giardina C, Martellotta M, Natale T, Ferrarese F. Prognostic factors in breast cancer: the predictive value of the Nottingham prognostic index in patients with a long-term follow-up that were treated in a single institution. Eur J Cancer. 2001;37(5):591-6.

52. Okugawa H, Yamamoto D, Uemura Y, Sakaida N, Yamada M, Tanaka K, Kamiyama Y. Prognostic factors in breast cancer: the value of the Nottingham prognostic index for patients treated in a single institution. Surg Today. 2009;8(39):738.

53. Haybittle JL, Blamey RW, Elston CW, Johnson J, Doyle PJ, Campbell FC, Nicholson Rl, Griffiths K. A prognostic index in primary breast cancer. $\mathrm{Br}$ J Cancer. 1982;45(3):361-6.

54. Rejali M, Tazhibi M, Mokarian F, Gharanjik N, Mokarian R. The performance of the Nottingham prognosis index and the adjuvant!Online decision 
making tool for prognosis in early-stage breast Cancer patients. Int J Prev Med. 2015:6:93.

55. Masarwah A, Auvinen P, Sudah M, Dabravolskaite V, Arponen O, Sutela A, Oikari S, Kosma VM, Vanninen R. Prognostic contribution of mammographic breast density and HER2 overexpression to the Nottingham prognostic index in patients with invasive breast cancer. BMC Cancer. 2016;16:833.

56. Fan YP, Liu CL, Chiang IJ, Lin CY. Development of a prognostic nomogram for identifying those factors which influence the 2- and 5-year survival chances of Taiwanese women diagnosed with breast cancer. Eur J Cancer Care. 2011;20(5):620-6.

57. Wen J, Ye F, He X, Li S, Huang X, Xiao X, Xie X. Development and validation of a prognostic nomogram based on the log odds of positive lymph nodes (LODDS) for breast cancer. Oncotarget. 2016;7(15):21046-53.

58. Hajage D, de Rycke Y, Bollet M, Savignoni A, Caly M, Pierga J, Horlings HM, Van de Vijver MJ, Vincent-Salomon A, Sigal-Zafrani B. External validation of Adjuvant!Online breast cancer prognosis tool. Prioritising recommendations for improvement. PLoS One. 2011;6(11):e27446.

59. Campbell HE, Taylor MA, Harris AL, Gray AM. An investigation into the performance of the adjuvant!Online prognostic programme in early breast cancer for a cohort of patients in the United Kingdom. Br J Cancer. 2009; 101(7):1074-84.

60. Quintyne KI, Woulfe B, Coffey JC, Gupta RK. Correlation between Nottingham prognostic index and adjuvant!Online prognostic tools in patients with early-stage breast cancer in mid-Western Ireland. Clin Breast Cancer. 2013;13(4):233-8.

61. Bhoo-Pathy N, Yip C, Hartman M, Saxena N, Taib NA, Ho G, Looi L, Bulgiba $A M$, van der Graaf $Y$, Verkooijen HM. Adjuvant!Online is overoptimistic in predicting survival of Asian breast cancer patients. Eur J Cancer. 2012;48(7): 982-9.

62. Kuo Y, Chen D, Change T. Accuracy validation of adjuvant!Online in Taiwanese breast cancer patients: a 10-year analysis. BMC Med Inf Decis Mak. 2012;12(1):108.

63. Plakhins G, Irmejs A, Gardovskis A, Subatniece S, Liepniece-Karele I, Purkalne G, Teibe U, Trofimovics G, Miklasevics E, Gardovskis J. Underestimated survival predictions of the prognostic tools adjuvant!Online and PREDICT in BRCA1-associated breast cancer patients. Familial Cancer. 2013;12(4):683.

64. Mook S, Schmidt MK, Rutgers EJ, van de Velde AO, Visser O, Rutgers SM, Armstrong N, van't Veer LJ, Ravdin PM. Calibration and discriminatory accuracy of prognosis calculation for breast cancer with the online adjuvant! Program: a hospital-based retrospective cohort study. Lancet Oncol. 2009;10(11):1070-6.

65. Mojir Sheibani K, Novin K, Tabatabaeefar M, Azadeh P, Mafi AR, Moghadam S, Kamal FH, Motlagh AG. The validation study of adjuvant!Online using Iranian breast cancer data. Rep Radiother Oncol. 2013;1 (3):97-102.

66. de Glas NA, van de Water W, Engelhardt EG, Bastiaannet E, de Craen AJM, Kroep JR, Putter H, Stiggelbout AM, Weijl NI, van de Velde CJH. Validity of adjuvant!Online program in older patients with breast cancer: a populationbased study. Lancet Oncol. 2014;15(7):722-9.

67. Wong HS, Subramaniam S, Alias Z, Taib NA, Ho GF, Ng CH, Yip CH, Verkooijen HM, Hartman M, Bhoo-Pathy N. The predictive accuracy of PREDICT: a personalized decision-making tool for southeast Asian women with breast cancer. Medicine (Baltimore). 2015;94(8):e593.

68. Laas E, Mallon P, Delomenie M, Gardeux V, Pierga JY, Cottu P, Lerebours F, Stevens D, Rouzier R, Reyal F. Are we able to predict survival in ER-positive HER2-negative breast cancer? A comparison of web-based models. Br J Cancer. 2015;112(5):912-7.

69. de Glas NA, Bastiaannet E, Engels CC, de Craen AJM, Putter H, van de Velde CHH, Hurria A, Liefers GJ, JEA P. Validity of the online PREDICT tool in older patients with breast cancer: a population-based study. Br J Cancer. 2016;114(4):395-400.

70. Megha T, Neri A, Malagnino V, Caruso S, Onorati M, Roviello F, Tosi P. Traditional and new prognosticators in breast cancer: Nottingham index, Mib-1 and oestrogen receptor signalling remain the best predictors of relapse and survival in a series of 289 cases. Cancer Biol Ther. 2010;9(4):266-73.

71. Sidoni A, Bellezza G, Cavaliere A, Del Sordo R, Scheibel M, Bucciarelli E. Prognostic indexes in breast cancer: comparison of the Nottingham and Adelaide indexes. Breast. 2004;13(1):23-7.

72. Sundquist M, Thorstenson S, Brudin L, Nordenskjöld B. Applying the Nottingham prognostic index to a Swedish breast cancer population. Breast Cancer Res Treat. 1999;53(1):1-8.

73. van Belle V, Decock J, Hendrickx W, Brouckaert O, Pintens S, Moerman P, Wildiers H, Paridaens R, Christiaens MR, Van Huffel S, Neven P. Short-term prognostic index for breast Cancer: NPI or Lpi. Pathol Res Int. 2010;2011: 918408.

74. Liu M, Huang W, Wang A, Huang C, Huang C, Chang T, Pi C, Yang H. Prediction of outcome of patients with metastatic breast cancer: evaluation with prognostic factors and Nottingham prognostic index. Support Care Cancer. 2010;18(12):1553-64.

75. Albergaria A, Ricardo S, Milanezi F, Carneiro V, Amendoeira I, Vieira D, Cameselle-Teijeiro J, Schmitt F. Nottingham prognostic index in triplenegative breast cancer: a reliable prognostic tool? BMC Cancer. 2011;11(1):299.

76. Thompson SG. Why and how sources of heterogeneity should be investigated. In: Egger M, Smith GD, Altman DG, editors. Systematic reviews in health care: meta-analysis in context. 2nd ed. London: BMJ; 2001. p. 157-75.

77. Collins GS, de Groot JA, Dutton S, Omar O, Shanyinde M, Tajar A, Voysey M, Wharton R, Yu L, Moons KG. External validation of multivariable prediction models: a systematic review of methodological conduct and reporting. BMC Med Res Methodol. 2014;14(1):40.

78. dos Reis FJ C, Wishart GC, Dicks EM, Greenberg D, Rashbass J, Schmidt MK, van den Broek AJ, Ellis IO, Green A, Rakha E, Maishman T, Eccles DM, PDP P. An updated PREDICT breast cancer prognostication and treatment benefit prediction model with independent validation. Breast Cancer ReS. 2017; 19(1):58.

79. Blettner M, Sauerbrei W, Schlehofer B, Scheuchenpflug T, Friedenreich C. Traditional reviews, meta-analyses and pooled analyses in epidemiology. Int J Epidemiol. 1999;28(1):1-9.

80. Mallett S, Royston P, Dutton S, Waters R, Altman DG. Reporting methods in studies developing prognostic models in cancer: a review. BMC Med. 2010; 8(1):20.

81. Bouwmeester W, Zuithoff NPA, Mallett S, Geerlings MI, Vergouwe Y, Steyerberg EW, Altman DG, Moons KGM. Reporting and methods in clinical prediction research: a systematic review. PLoS Med. 2012;9(5):e1001221.

82. Schumacher M, Hollaander N, Schwarzer G, Sauerbrei W. Prognostic factor studies. In: Crowley J, editor. Handbook of Statistics in Clinical Oncology. New York: Marcel Dekker; 2001. p. 321-78.

83. Harrell FE Jr, Lee KL, Matchar DB, Reichert TA. Regression models for prognostic prediction: advantages, problems, and suggested solutions. Cancer Treat Rep. 1985;69(10):1071-7.

84. Feinstein AR. Multivariable analysis: an introduction. New Haven: Yale University press; 1996.

85. Collins GS, Ogundimu EO, Altman DG. Sample size considerations for the external validation of a multivariable prognostic model: a resampling study. Stat Med. 2016;35(2):214-26

86. Vergouwe Y, Moons KGM, Steyerberg EW. External validity of risk models: use of benchmark values to disentangle a case-mix effect from incorrect coefficients. Am J Epidemiol. 2010;172(8):971-80.

87. Peek N, Arts DGT, Bosman RJ, van der Voort PHJ, de Keizer NF. External validation of prognostic models for critically ill patients required substantial sample sizes. J Clin Epidemiol. 2007:60(5):491-501.

88. Cianfrocca M, Goldstein LJ. Prognostic and predictive factors in early-stage breast cancer. Oncologist. 2004;9(6):606-16.

89. Hawkins RA, Tesdale AL, Prescott RJ, Forster T, McIntyre MA, Baker P, Jack WJL, Chetty U, Dixon JM, Killen ME, Hulme MJ, Miller WR. Outcome after extended follow-up in a prospective study of operable breast cancer: key factors and a prognostic index. Br J Cancer. 2002;87(1):8-14.

90. Rakha EA, Soria D, Green AR, Lemetre C, Powe DG, Nolan CC, Garibaldi JM, Ball G, Ellis IO. Nottingham prognostic index plus (NPI+): a modern clinical decision making tool in breast cancer. Br J Cancer. 2014;110(7):1688-97.

91. Suen D, Chow LWC. Prognostic contribution of the HER-2 oncogene overexpression to the Nottingham prognostic index in breast cancer. Biomed Pharmacother. 2006;60(6):293-7.

92. West M, Blanchette C, Dressman H, Huang E, Ishida S, Spang R, Zuzan H, Olson JA Jr, Marks JR, Nevins JR. Predicting the clinical status of human breast cancer by using gene expression profiles. Proc Natl Acad Sci U S A. 2001;98(20):11462-7.

93. Huang E, Cheng SH, Dressman H, Pittman J, Tsou MH, Horng CF, Bild A, Iversen ES, Liao M, Chen CM. Gene expression predictors of breast cancer outcomes. Lancet. 2003;361(9369):1590-6.

94. Parisi F, González AM, Nadler Y, Camp RL, Rimm DL, Kluger HM, Kluger Y. Benefits of biomarker selection and clinico-pathological covariate inclusion in breast cancer prognostic models. Breast Cancer Res. 2010;12(5):R66.

95. Tang G, Cuzick J, Costantino JP, Dowsett M, Forbes JF, Crager M, Mamounas EP, Shak S, Wolmark N. Risk of recurrence and chemotherapy benefit for 
patients with node-negative, oestrogen receptor-positive breast cancer: recurrence score alone and integrated with pathologic and clinical factors. J Clin Oncol. 2011;29(33):4365-72.

96. Mallett S, Royston P, Waters R, Dutton S, Altman DG. Reporting performance of prognostic models in cancer: a review. BMC Med. 2010;8(1):21.

97. Gomez-Ruiz JA, Jerez-Aragones JM, Munoz-Perez J, Alba-Conejo E. A neural network based model for prognosis of early breast cancer. Appl Intell. 2004; 20(3):231-8.

98. Collan Y, Kumpusalo L, Pesonen E, Eskelinen M, Pajarinen P, Kettunen K. Prediction of survival in breast cancer: evaluation of different multivariate models. Anticancer Res. 1998;18(1B):647-50.

99. Steyerberg EW, Vergouwe Y. Towards better clinical prediction models: seven steps for development and an ABCD for validation. Eur Heart J. 2014;35(29):1925-31.

100. Riley RD, Ensor J, Snell KI, Debray TP, Altman DG, Moons KG, Collins GS. External validation of clinical prediction models using big datasets from e-health records or IPD meta-analysis: opportunities and challenges. BMJ. 2016:353:i3140.

101. Laupacis A, Sekar N. Clinical prediction rules: a review and suggested modifications of methodological standards. JAMA. 1997;277(6):488-94.

102. Boutron I, Dutton S, Ravaud P, Altman DG. Reporting and interpretation of randomised controlled trials with statistically nonsignificant results for primary outcomes. JAMA. 2010;303(20):2058-64.

103. Kuehn BM. Striving for a more perfect peer review: editors confront strengths, flaws of biomedical literature. JAMA. 2013;310(17):1781-3.

104. Ochodo EA, de Haan MC, Reitsma JB, Hooft L, Bossuyt PM, Leeflang MM. Overinterpretation and misreporting of diagnostic accuracy studies: evidence of "spin". Radiology. 2013:267(2):581-8.

105. Altman DG, Vergouwe $Y$, Royston P, Moons KG. Prognosis and prognostic research: validating a prognostic model. BMJ. 2009;338:b605.

106. Lundin J. The Nottingham prognostic index-from relative to absolute risk prediction. Eur J Cancer. 2007;43(10):1498-500

107. Asare EA, Liu L, Hess KR, Gordon EJ, Paruch JL, Palis B, Dahlke AR, McCabe R, Cohen ME, Winchester DP, Bilimoria KY. Development of a model to predict breast cancer survival using data from the National Cancer Data Base. Surgery. 2016;159(2):495-502.

108. Baak J, van Dop H, Kurver PHJ, Hermans JO. The value of morphometry to classic prognosticators in breast cancer. Cancer. 1985;56(2):374-82.

109. Broet $P$, de la Rochefordiere A, Scholl SM, Fourquet A, de Rycke $Y$, Pouillart $P$, Mosseri $V$, Asselain B. Analysing prognostic factors in breast cancer using a multistate model. Breast Cancer Res Treat. 1999;54(1):83-9.

110. Brown JM, Benson EA, Jones M. Confirmation of a long-term prognostic index in breast cancer. Breast. 1993;2(3):144-7.

111. Bryan RM, Mercer RJ, Bennett RC, Rennie GC. Prognostic factors in breast cancer and the development of a prognostic index. Br J Surg. 1986;73(4):267-71.

112. Bucinski A, Baczek T, Kaliszan R, Nasal A, Krysinski J, Zaluski J. Artificial neural network analysis of patient and treatment variables as a prognostic tool in breast cancer after mastectomy. Adv Clin Exp Med. 2005;14(5):973-9.

113. Collan Y, Eskelinen MJ, Nordling SA, Lipponen P, Pesonen E, Kumpusalo LM, Pajarinen $\mathrm{P}$, Kettunen $\mathrm{KO}$. Prognostic studies in breast cancer: multivariate combination of nodal status, proliferation index, tumour size, and DNA ploidy. Acta Oncol. 1994;33(8):873-8.

114. Fuster E, Garcia-Vilanova A, Narbona B, Romero R, Llombart-Bosch A. A statistical approach to an individualized prognostic index (IPI) for breast cancer survivability. Cancer. 1983;52(4):728-36.

115. Jerez Aragonés JM, Peláez Sánchez JI, Dona JM, Alba E. A neuro-fuzzy decision model for prognosis of breast cancer relapse. In: Conejo R, Urretavizcaya M, Perez-de-la-Cruz J, editors. Lecture Notes in Computer Science. Volume 3040. Berlin: Springer; 2004. p. 638-45.

116. Jhajharia S, Varshney HK, Verma S, Kuma J. A neural network based breast cancer prognosis model with PCA processed features. Jaipur, India: Proceedings of the 2016 International Conference on Advances in Computing, Communications and Informatics (ICACCI); 2016.

117. Kim W, Kim KS, Park RW. Nomogram of naive Bayesian model for recurrence prediction of breast cancer. Healthc Inform Res. 2016;22(2):89-94.

118. Liu YQ, Cheng W, Lu Z. Decision tree based predictive models for breast cancer survivability on imbalanced data. Proceedings of the 2009 3rd international conference on bioinformatics and biomedical engineering: 2009; Beijing, China. 2009.

119. Lovekin C, Ellis 1O, Locker A, Robertson JFR, Bell J, Nicholson R, Gullick WJ, Elston CW, Blamey RW. C-erbB-2 oncoprotein expression in primary and advanced breast cancer. Br J Cancer. 1991;63(3):439-43.
120. Mazouni C, Bonnier P, Romain S, Martin PM. A nomogram predicting the probability of primary breast cancer survival at 2- and 5-years using pathological and biological tumor parameters. J Surg Oncol. 2011;103(8):746-50.

121. Musial M, Grodecka-Gazdecka S, Kycler W. Prognostic index in lobular breast cancer. Rep Pract Oncol Radiother. 2005;10(4):165-72.

122. Ni YB, Tsang JYS, Chan SK, Tse GM. A novel morphologic-molecular recurrence predictive model refines traditional prognostic tools for invasive breast carcinoma. Ann Surg Oncol. 2014;21(9):2928-33.

123. Paik S, Hazan R, Fisher ER, Sass RE, Fisher B, Redmond C, Schlessinger J, Lippman ME, King CR. Pathologic findings from the National Surgical Adjuvant Breast and bowel project: prognostic significance of erbB-2 protein overexpression in primary breast cancer. J Clin Oncol. 1990;8(1):103-12.

124. Putter $H$, van der Hage J, de Bock $G H$, Elgalta $R$, van de Velde CJ. Estimation and prediction in a multi-state model for breast cancer. Biom J. 2006;48(3):366-80.

125. Ravdin PM, Siminoff LA, Davis GJ, Mercer MB, Hewlett J, Gerson N, Parker $\mathrm{HL}$. Computer program to assist in making decisions about adjuvant therapy for women with early breast cancer. J Clin Oncol. 2001;19(4):980-91.

126. Sanghani M, Balk E, Cady B, Wazer D. Predicting the risk of local recurrence in patients with breast cancer: an approach to a new computer-based predictive tool. Am J Clin Oncol. 2007;30(5):473-80.

127. Shek LLM, Godolphin W. Model for breast-Cancer survival - relative prognostic roles of axillary nodal status, TNM stage, oestrogen-receptor concentration, and tumour necrosis. Cancer Res. 1988;48(19):5565-9.

128. van Nes JGH, Putter H, van Hezewijk M, Hille ETM, Bartelink H, Collette L, van de Velde CJH. EORTC breast Canc grp: tailored follow-up for early breast cancer patients: a prognostic index that predicts locoregional recurrence. Ejso. 2010;36(7):617-24.

129. Wen J, Ye F, Li S, Huang X, Yang L, Xiao X, Xie X. The practicability of a novel prognostic index (PI) model and comparison with Nottingham prognostic index (NPI) in stage I-II| breast cancer patients undergoing surgical treatment. PLoS One. 2015;10(11):e0143537.

130. Aaltomaa S, Lipponen P, Eskelinen M, Kosma VM, Marin S, Alhava E, Syrjänen K. Predictive value of a morphometric prognostic index in female breast cancer. Oncology. 1993;50(1):57-62.

131. Alexander Al, Mercer RJ, Muir IM, Bennett RC, Rennie GC. Validation of a prognostic index in breast cancer. ANZ J Surg. 1987;57(6):399-403.

132. Carbone A, Serra FG, Rinelli A, Terribile D, Valentini M, Bellantone R, Rossi S, Ausili-Cefaro G, Nardone L, Piantelli M, Capelli A, Ranelletti FO. Morphometric prognostic index in breast cancer. Anal Quant Cytol Histol. 1999;21(3):250-4.

133. Green AR, Soria D, Stephen J, Powe DG, Nolan CC, Kunkler I, Thomas J, Kerr GR, Jack W, Cameron D. Nottingham prognostic index plus: validation of a clinical decision making tool in breast cancer in an independent series. J Pathol. 2016;2(1):32-40.

134. Jung SP, Hur SM, Lee SK, Kim S, Choi M, Bae SY, Kim J, Kim MK, Kil WH, Choe J. Validation of a web-based tool to predict the ipsilateral breast tumour recurrence (IBTR! 2.0) after breast-conserving therapy for Korean patients. J Breast Cancer. 2013;16(1):97-103.

135. Kindts I, Laenen A, Peeters S, Janssen H, Depuydt T, Nevelsteen I, Van Limbergen E, Weltens C. Validation of the Web-Based IBTR! 2.0 Nomogram to Predict for Ipsilateral Breast Tumor Recurrence After Breast-Conserving Therapy. Int J Radiat Oncol Biol Phys. 2016;95(5):1477-84.

136. Lende TH, Janssen EAM, Gudlaugsson E, Voorhorst F, Smaaland R, van Diest $P$, Søiland $H$, Baak JPA. In patients younger than age 55 years with lymph node-negative breast cancer, proliferation by mitotic activity index is prognostically superior to adjuvant! J Clin Oncol. 2010;29(7):852-8.

137. Maishman T, Copson E, Stanton L, Gerty S, Dicks E, Durcan L, Wishart GC, Pharoah $\mathrm{P}$, Eccles D. An evaluation of the prognostic model PREDICT using the POSH cohort of women aged $\leqslant 40$ years at breast cancer diagnosis. $\mathrm{Br} J$ Cancer. 2015;112(6):983-91.

138. Miao H, Hartman M, Verkooijen HM, Taib NA, Wong H, Subramaniam S, Yip C, Tan E, Chan P, Lee S. Validation of the CancerMath prognostic tool for breast cancer in Southeast Asia. BMC Cancer. 2016;16(1):820.

139. Ribelles N, Barnadas A, Lopez D, Vaquero M, Rosell R, Sanchez J. Validation of breast cancer prognostic models. Oncol Rep. 1997;4(2):419-23.

140. Altman DG. Analysis of Survival times. In: Altman DG, editor. Practical statistics for Medical research. 1st ed. London: Chapman and Hall; 1992. p. 365-93.

141. Bland JM, Altman DG. The log-rank test. BMJ. 2004;328(7447):1073.

142. Heller G, Mo Q. Estimating the concordance probability in a survival analysis with a discrete number of risk groups. Lifetime Data Anal. 2016;22(2):263-79.

143. Verweij PJM, van Houwelingen HC. Cross-validation in survival analysis. Stat Med. 1993;12(24):2305-14 